\title{
Zabezpečenost odběrů vody $z$ vodárenských nádrží v podmínkách klimatické změny
}

\section{ADAM VIZINA, PETR VYSKOČ, MARTINA PELÁKOVÁ, JIŘÍ PICEK, ADAM BERAN, ROMAN KOŽÍN}

Klíčová slova: klimatická změna - vodní zdroje nedostatek vody - zásobování pitnou vodou - vodní bilance

\section{Preservation of drinking water demand from water reservoirs in climate change conditions}

\section{ADAM VIZINA, PETR VYSKOČ, MARTINA PELÁKOVÁ, JIŘÍ PICEK, ADAM BERAN, ROMAN KOŽÍN}

Keywords: climate change - water resources water scarcity - drinking water supply - water balance

\section{SOUHRN}

Článek představuje průběžné výsledky vyhodnocení možného dopadu klimatické změny na zabezpečenost odběrů vody pro vodárenské účely zajištovaných vodními nádržemi k časové úrovni roku 2050. Při řešení byly aplikovány postupy hydrologické a vodohospodářské bilance, včetně modelování zásobní funkce vodohospodářských soustav. Možný dopad klimatické změny na hydrologické charakteristiky a následně na zabezpečenost odběrů vody byl vyhodnocen u celkem 45 vodních nádrží v ČR. Riziko nedostatečného zajištění současných požadavků na vodárenské odběry v podmínkách klimatické změny bylo identifikováno u 17 zhodnocených vodních nádrží.

\section{ÚVOD}

Sucho spolu s povodněmi patři k extrémním hydrologickým jevům, ke kterým dochází prírozeně a nahodile. S rostoucími dopady klimatické změny se však frekvence výskytu i časový a plošný rozsah extrémních hydrologických jevů může měnit. Výsledky modelování dopadů klimatické změny pro ČR předpovídají četnější výskyt prívalových povodní a dlouhotrvajícího sucha. Tato skutečnost se $v$ posledních letech potvrzuje na mnoha povodích. Nepríznivá situace může vést i k ohrožení spolehlivosti zásobování obyvatel pitnou vodou. Významná část odběrů vody pro vodárenské účely je v ČR zajištována prostřednictvím vodních nádrží. Podle aktuálních dat evidovaných pro potřebu sestavení vodní bilance [1] je pomocí vodních nádrží (a to jak odběry vody prímo z vodních nádrží, tak nadlepšováním průtoků do míst odběrů vody níže položených) zajištováno cca 50 \% z celkového množství vody odebrané pro veřejné vodovody ( $92 \%$ z odběrů povrchových vod pro veřejné vodovody).

Prezentované vyhodnocení zabezpečení vodárenských odběrů zajištovaných vodními nádržemi bylo zpracováno v rámci řešení projektu VI20192022159 „Vodohospodářské a vodárenské soustavy a preventivní opatření ke snižení rizik při zásobování pitnou vodou“ programu BV III/1-VS Ministerstva vnitra. Řešitelem projektu je Výzkumný ústav vodohospodářský T. G. Masaryka, v. v. i. Řešení projektu bylo zahájeno v červenci 2019, dokončení je plánováno na prosinec 2022. Projekt je zaměřen na vyhodnocení rizik zásobování pitnou vodou $\checkmark$ důsledku klimatické změny a vytvoření technických nástrojů pro posouzení možných opatření ke zmírnění prípadných nepríznivých dopadů.

\section{SUMMARY}

This study presents interim results of an evaluation of a potential climate change impact on the preservation of drinking water demand provided by water reservoirs in the timeframe of the year 2050. Hydrological and water sources and demands balance procedures have been applied, including modelling of the storage ability of water resources and water supply systems. A potential climate change impact on hydrological characteristics and subsequently on the security of water demand has been evaluated in a total of 45 water reservoirs in the Czech Republic. A risk of insufficient supply of current drinking water abstraction requirements in climate change conditions has been identified in 17 of the evaluated water reservoirs.

\section{INTRODUCTION}

Drought together with floods belong among extreme hydrological phenomena that occur naturally and randomly. However, with increasing climate change impacts, frequency of the occurrence, temporal and spatial distribution of extreme hydrological phenomena may change. The results of modelling climate change impacts for the Czech Republic predict a more frequent occurrence of flash floods and long-lasting drought. In recent years, this fact has been proven in many catchment areas. An unfavourable situation may even lead to putting the reliability of drinking water supply for citizens at risk. A significant part of drinking water demand in the Czech Republic is provided by water reservoirs. According to current data recorded for the sake of water balance compilation [1], approximately $50 \%$ of the total water demand for public water mains (92\% of surface water for public water mains) are provided for by water reservoirs (both by water abstraction directly from water reservoirs and by ameliorating discharge to water abstraction sites at lower altitudes).

The presented evaluation of the preservation of drinking water demand provided for by water reservoirs has been made within project No. VI20192022159 "Water Resources and Water Supply Systems and Preventive Measures to Reduce Risks for Drinking Water Supply" under a Ministry of the Interior programme No. BV III/1-VS. The T. G. Masaryk Water Research Institute is the project investigator. Work on the project was launched in July 2019 and is envisaged to be 


\section{METODIKA A MATERIÁL}

Posouzení možných dopadů klimatické změny na zajištění vodárenských odběrů vodními nádržemi vychází z metodiky [2]. Při řešení jsou aplikovány $\checkmark$ metodice uvedené postupy zpracování hydrologické a vodohospodáŕské bilance, včetně simulačního modelování zásobní funkce vodohospodářských soustav. Posouzení bylo zpracováno k výhledovému období roku 2050.

Dopad klimatické změny na hydrologické charakteristiky a zabezpečenost odběrů vody byly posouzeny u vodních nádrží evidovaných jako vodárenské podle [3] (s výjimkou vodních nádrží Husinec, Jezeří, Boskovice a Fryšták, které nejsou v současnosti pro vodárenské odběry využívány). Rovněž byla posouzena zabezpečenost vodárenských odběrů z vodních nádrží Seč, Vranov a Slezská Harta. Kromě odběrů vody z těchto nádrží byly posuzovány i vodárenské odběry vody na vodních tocích, kam je průtok z vodních nádrží pro potřebu zajištění odběrů aktivně nadlepšován (ÚV Plzeň na Úhlavě z vodní nádrže Nýrsko, ÚV Milíkov na Mži z vodní nádrže Lučina) nebo převáděn (ÚV Šumná na Bílém potoce z vodní nádrže Fláje). Uvažovány byly převody vody z Třebízského potoka a z vodní nádrže Podhora do vodní nádrže Mariánské Lázně, z Černé vody do vodní nádrže Přísečnice, z vodní nádrže Fláje do Pekelského potoka (pro Úv Šumná), z Lužce do vodní nádrže Jirkov, z Jiřínského a Jedlovského potoka do vodní nádrže Hubenov. Při simulaci zásobní funkce byla rovněž uvažována možnost spolupráce či vzájemná zastupitelnost vodních nádrží Karhov - Zhejral, Podhora - Mariánské Lázně, Vranov - Znojmo, Seč Křižanovice, Slezská Harta - Kružberk a Morávka - Šance.

\section{Současné klimatické podmínky}

Pro samotné hodnocení současných podmínek byla využita data za období 1941-2017, a to časové řady teplot vzduchu, srážkových úhrnů a odtoků. Na obr. 1 jsou znázorněny odchylky průměrných ročních teplot vzduchu od průměrné roční teploty za referenční období 1981-2010 (znázorněno žlutým polygonem). Lze pozorovat výrazný nárůst teplot, a to predevším v posledních letech. Tento nárůst teplot je statisticky významný na vysoké hladině významnosti. Zeleně jsou zobrazena období tří nejvýznamnějších such v tomto časovém úseku. Zvyšující se teplota má vliv na velikost potenciální evapotranspirace, a pokud je k dispozici voda v půdním profilu, tak samozřejmě i na aktuální výpar.

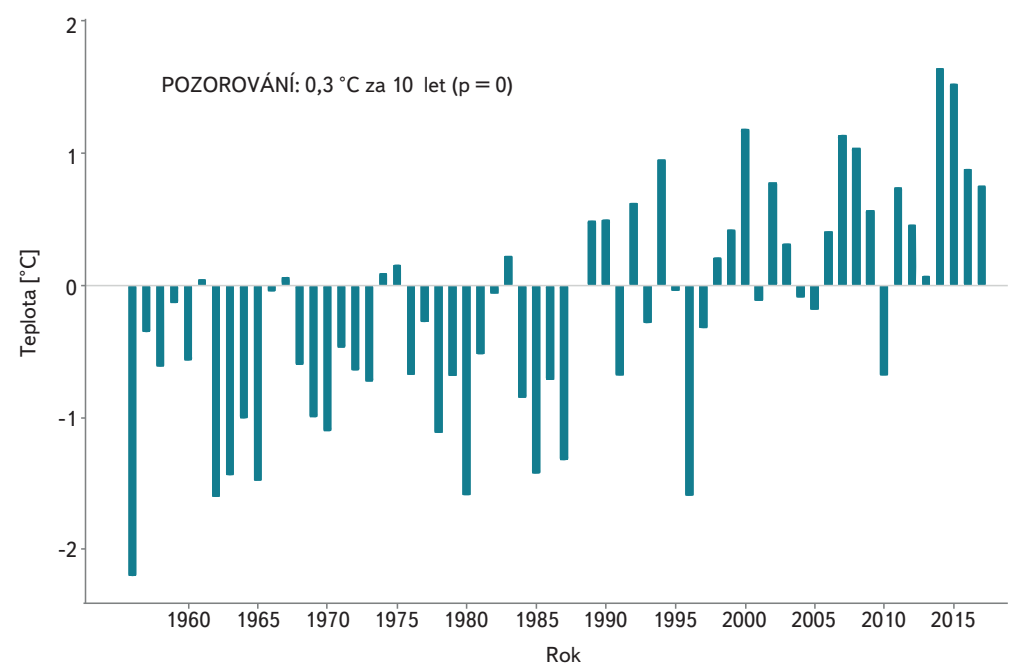

Obr. 1. Prưměrné roční teploty vzduchu za období 1955-2017 (trend 0,3 ${ }^{\circ} \mathrm{C}$ za 10 let, který je statisticky významný) completed in December 2022. The project focuses on evaluating risks of drinking water supply as a result of climate change and on devising technical tools for assessing possible measures to mitigate potential unfavourable impacts.

\section{METHODOLOGY AND MATERIAL}

The assessment of potential climate change impacts on the preservation of drinking water demand from water reservoirs is based on a methodology [2]. Procedures for processing hydrological and water management balance stated in the methodology have been applied in the project, including simulation modelling of the storage ability of water management systems (water reservoirs). The assessment has been made for the prospective period of 2050.

The climate change impact on hydrological characteristics and on the security of water demand have been assessed in water reservoirs that are recorded as water supply ones pursuant to [3] (with an exception of water reservoirs Husinec, Jezeří, Boskovice and Fryšták, which are at present not used for drinking water abstraction). At the same time, the security of drinking water demand from water reservoirs Seč, Vranov and Slezská Harta has also been assessed. Besides water abstraction from these reservoirs, drinking water demand has also been assessed on watercourses where discharge from water reservoirs is actively ameliorated for the sake of securing water demand (the Plzen water treatment plant on the Úhlava River from the Nýrsko water reservoir and the Milíkov water treatment plant on the Mže River from the Lučina water reservoir) or transferred (the Šumná water reservoir on Bílý Brook from the Fláje water reservoir). Water transfers from Třebízský Brook and from the Podhora water reservoir to the Mariánské Lázně water reservoir have been considered, from Černá voda Brook to the Prísečnice water reservoir and from the Fláje water reservoir to Pekelský Brook (for the Šumná water treatment plant), from Lužec Brook to the Jirkov water reservoir and from Jirínský Brook and Jedlovský Brook to the Hubenov water reservoir. When the storage function was simulated, the possibility of cooperation or mutual replaceability of water reservoirs Karhov Zhejral, Podhora - Mariánské Lázně, Vranov - Znojmo, Seč - Křižanovice, Slezská Harta - Kružberk and Morávka - Šance has also been considered.

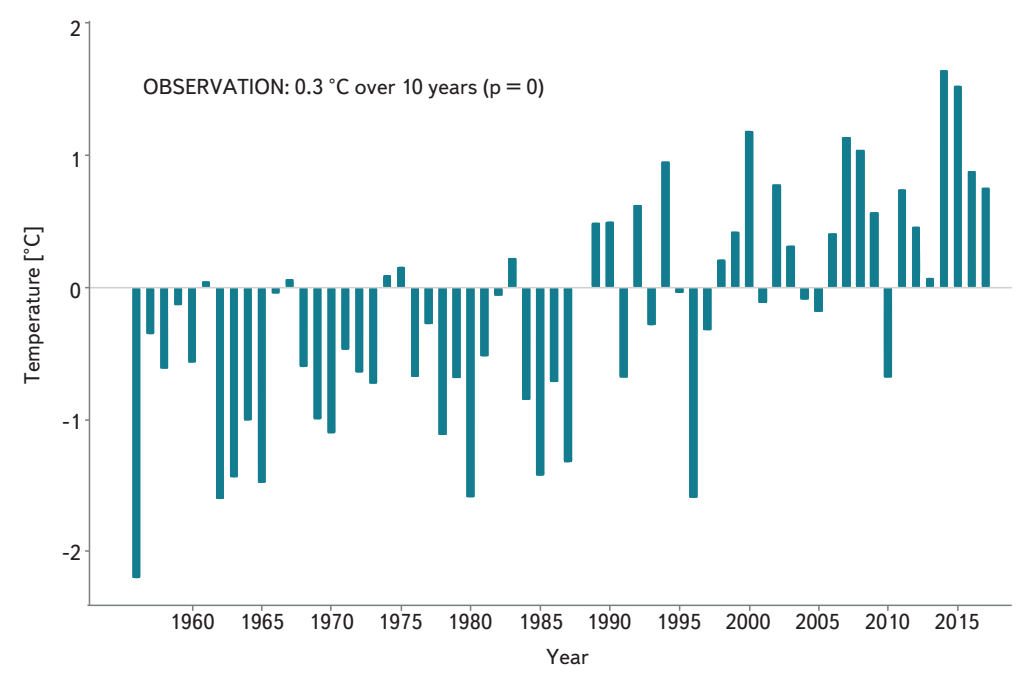

Fig. 1. Mean annual air temperature during the period of 1955-2017 (a statistically significant trend of $0.3^{\circ} \mathrm{C}$ over 10 years) 
Analogicky jsou na dalších grafech zobrazeny srážkové úhrny a odtokové výšky. Na obr. 2 lze vidět rozdíly srážkových úhrnů od referenčního období. Z nich je zřejmé, že se období, kdy byla snížená dostupnost srážkových úhrnů (1969-1974, 1989-1994, 2014-2017), opakuje, deficit byl dokonce větší než v posledních pěti letech. Vyhodnocení ročních srážkových úhrnů neukazuje trend, který by byl statisticky významný. Tento fakt lze odvodit také z obr. 3, který zachycuje odtokové výšky. Z dlouhodobého hlediska u průměrných ročních odtoků (průměrných za celé území ČR) nelze vysledovat statisticky významný trend. $\vee$ posledních letech však Ize pozorovat výrazný pokles odtoků v letních a jarních měsících a nárůst v měsíci lednu (což je dáno především nárůstem teplot - kapalnými srážkami a táním sněhu). Pro představu, změna odtoku o 1 mm znamená snížení o 78,87 mil. m³. Tato hodnota odpovídá téměř objemu vody ve VN Rozkoš.

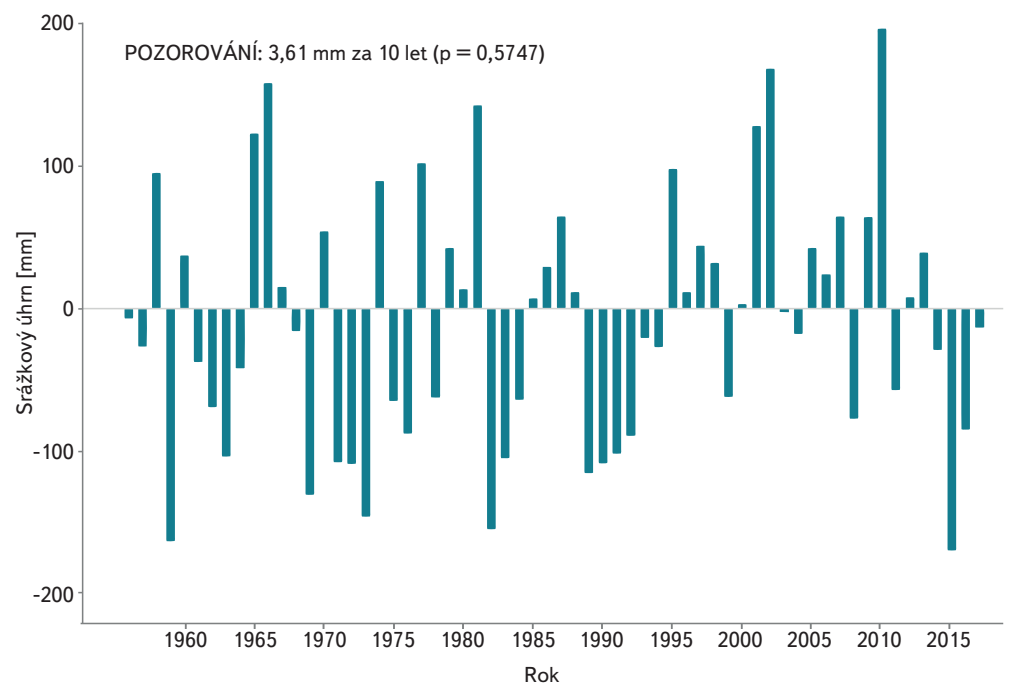

Obr. 2. Průměrné roční rozdíly srážkových úhrnů (od normálu) za období 1955-2017 (trend 3,61 mm za 10 let, který je statisticky nevýznamný)

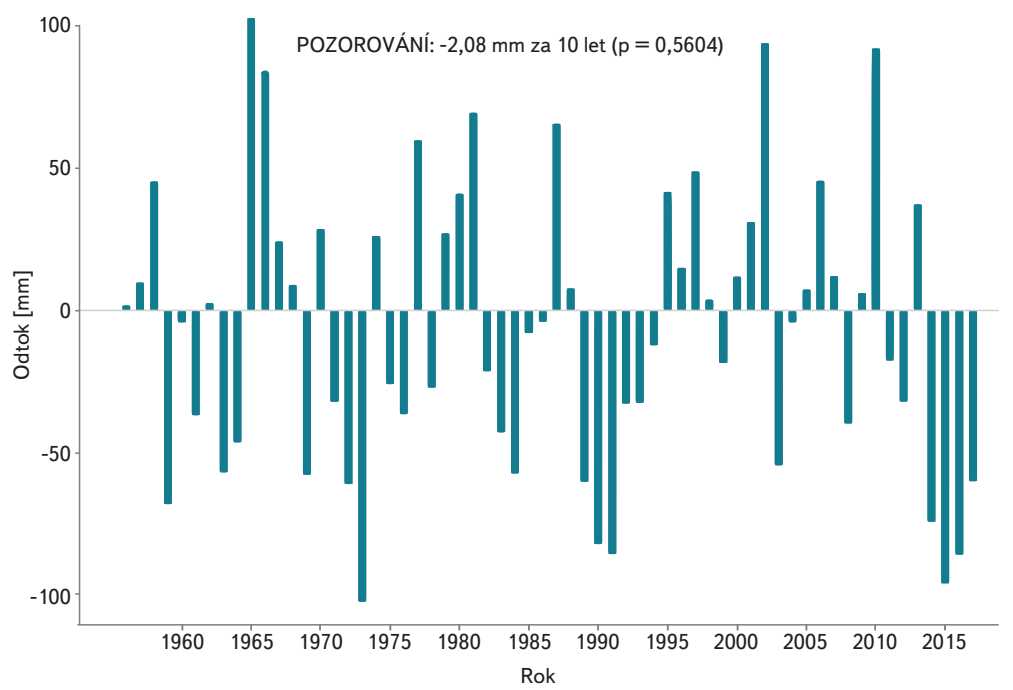

Obr. 3. Průměrné roční rozdíly odtoků (od normálu) za období 1955-2017 (trend -2,08 mm za 10 let, který je statisticky nevýznamný)

\section{Current Climate Conditions}

Data from the period of 1941-2017 have been used for the actual evaluation of current conditions, namely time series of air temperature, precipitation totals and runoff. Fig. 1 presents deviations of mean annual air temperature from the mean annual temperature over the reference period of 1981-2010 (represented by a yellow polygon). A significant temperature increase can be observed, especially in recent years. This temperature increase is statistically significant with a high degree of significance. The green colour represents periods of 3 most significant droughts in this period. Increasing temperature has an impact on the amount of potential evapotranspiration and if water is available in the soil profile, then naturally also on the actual evaporation.

By analogy, the following figures present precipitation totals and runoff heights. Fig. 2 shows the differences of precipitation totals from the reference period. We can see that the periods when precipitation totals were lower (1969-1974, 1989-1994, 2014-2017) repeat themselves and that the deficit was even higher than in the past five years. However, an evaluation of annual

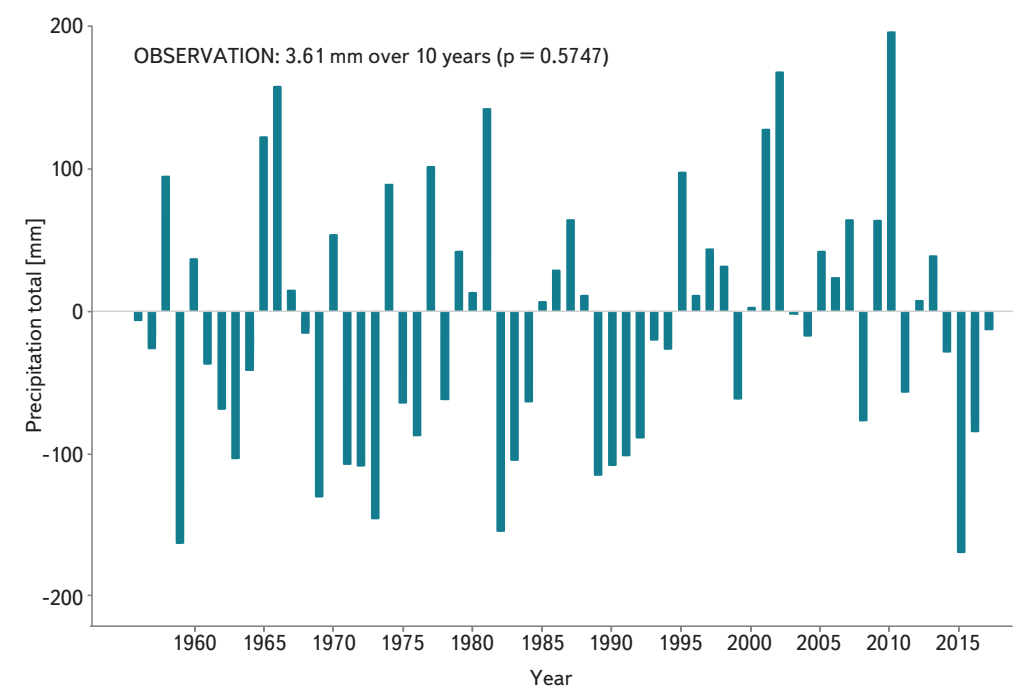

Fig. 2. Mean annual differences in precipitation totals (from normal) for the period of 1955-2017 (a statistically insignificant trend of $3.61 \mathrm{~mm}$ over 10 years)

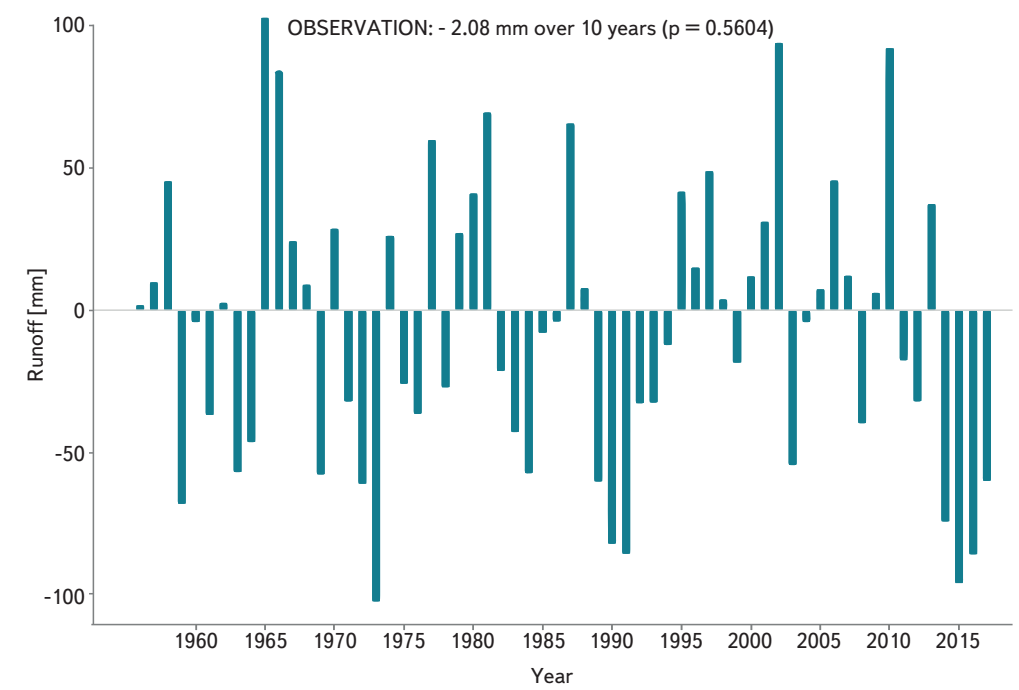

Fig. 3. Mean annual runoff differences (from normal) for the period of 1955-2017 (a statistically insignificant trend of $-2.08 \mathrm{~mm}$ over 10 years) 


\section{Scénáře změny klimatu ve vodním hospodářství}

Pro tvorbu scénářu změny klimatu $v$ kontextu odhadu změn hydrologické bilance se $v$ České republice standardně využivá tzv. prírůstková metoda, zejména pro studie $v$ měsíčním kroku. Tato metoda spočívá $v$ transformaci pozorovaných dat tak, aby změny transformovaných veličin odpovídaly změnám odvozeným ze simulací klimatických modelü. V měsíčním kroku se běžně uvažují změny průměrných měsíčních úhrnů srážek a průměrné měsíční teploty. $V$ denním kroku je nutné uvažovat i změny variability veličin. Pro tvorbu scénářů změny klimatu byla proto využita pokročilá prírůstková metoda ADC (Advanced Delta Change). Podstatou prírůstkové metody je transformace pozorovaných dat způsobem, jenž zaručí, že změny mezi transformovanou a původní řadou jsou stejné jako změny odvozené z regionálního klimatického modelu. U srážek a teploty (zejména v denním kroku) je žádoucí, aby uvažované transformace zohledňovaly změny jak v průměru, tak ve variabilitě. To zjednodušeně znamená, že extrémy se mohou měnit jinak než průměr. Při odvození změn srážek z klimatického modelu ADC metoda uvažuje i systematické chyby simulace. Jelikož teplota je transformována lineárně, nemá systematická chyba na výslednou transformaci teploty vliv [4].

Zvolenou metodou byly transformovány vybrané [5] Globální cirkulační modely (GCM) pro dílčí povodí, jedná se o:

- NorESM1-M +

- MPI-ESM-LR + HadGEM2-ES +

- GISS-E2-H + MRI-ESM1 +

- CanESM2 + GFDL-CM3

První model (NorESM1-M) představuje střed ansámblu všech GCM. Modely MPI-ESM-LR + HadGEM2-ES + vystupují jako rí́dící GCM pro několik EuroCORDEX RCM simulací. To ostatně platí i pro vybraný střední model, který rovněž řídí jeden z Euro-CORDEX RCMs. Modely GISS-E2-H + MRI-ESM1 zajistí splnění podmínky na pokrytí mezimodelové variability a modely CanESM2 + GFDL-CM3 umožní splnit poslední uvedenou podmínku výběru. Tyto modely byly dále testovány pro vodní hospodářství. Testovány byly také vybrané modely RCM. Pro samotné hodnocení byl vybrán model HadGEM2-ES, který byl pro střední scénář dopadů klimatické změny doporučen ve studii [6]. Vývoj teploty dle RCP8.5 je uveden na obr. 4.

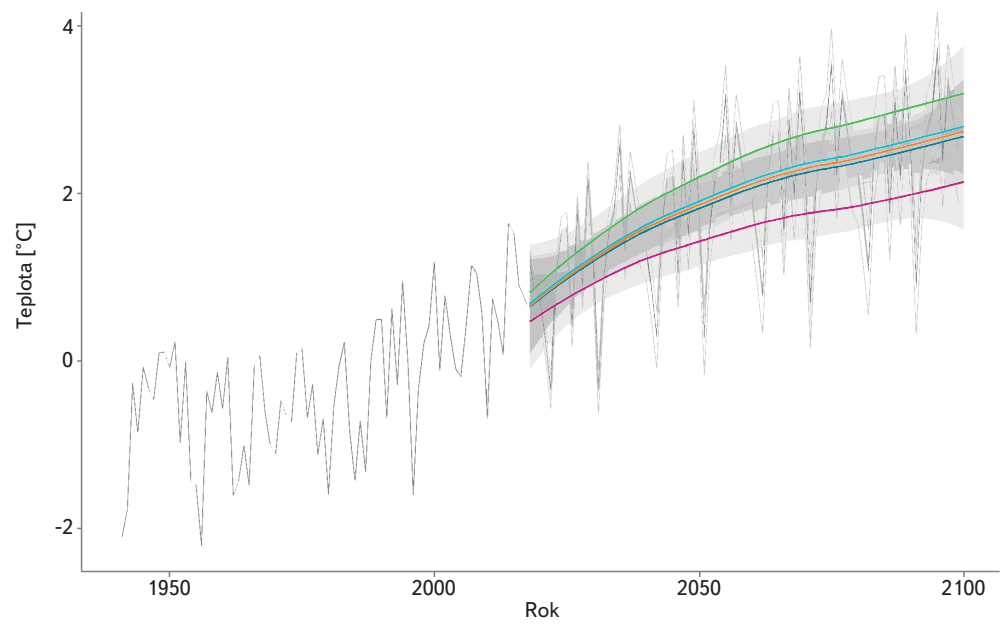

\section{SCEN}

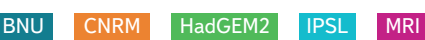

Obr. 4. Změny teploty vzduchu dle jednotlivých GCM a RCP8.5. precipitation totals does not yield a trend that would be statistically significant. This fact may also be derived from Fig. 3, which presents runoff heights. From the long-term perspective, no statistically significant trend can be established in mean annual runoff (that capture mean values for the whole territory of the Czech Republic). Nevertheless, a significant decline in runoff in the summer and spring months and an increase in January may be observed (which is in particular due to an increase in temperature - liquid precipitation and snow melting). For illustration, a change of runoff by $1 \mathrm{~mm}$ means a reduction by 78.87 million $\mathrm{m}^{3}$. This value corresponds nearly to the water volume in the Rozkoš water reservoir.

\section{Climate Change Scenarios in Water Management}

The increment method is used as a standard for calculating climate change scenarios in the context of predicting changes of hydrological balance in the Czech Republic, especially for studies with monthly time steps. This method is based on a transformation of observed data so that changes of transformed variables would correspond to changes derived from climate model simulations. The monthly time step usually considers changes of mean monthly precipitation totals and mean monthly temperature. The daily time step needs to consider also variability changes of variables. Therefore, the ADC (Advanced Delta Change) increment method has been used for calculating climate change scenarios. The increment method is based on a transformation of observed data in a way that ensures that changes between the transformed and original series are the same as changes derived from a regional climate model. Especially in the daily time step, it is desirable that considered transformations regarding precipitation and temperature take into account changes both in the mean and in the variability. To put it simply, this means that extremes may change differently from the mean. When precipitation changes are derived from the climate model, the ADC method takes into consideration also systematic simulation errors. Since temperature is transformed linearly, a systematic error does not have an impact on the resulting temperature transformation [4].

The chosen method has been used to transform selected [5] Global Circulation Models (GCMs) for sub-catchment areas, namely:

- NorESM1-M +

- MPI-ESM-LR + HadGEM2-ES +

- GISS-E2-H + MRI-ESM1 +

- CanESM2 + GFDL-CM3.

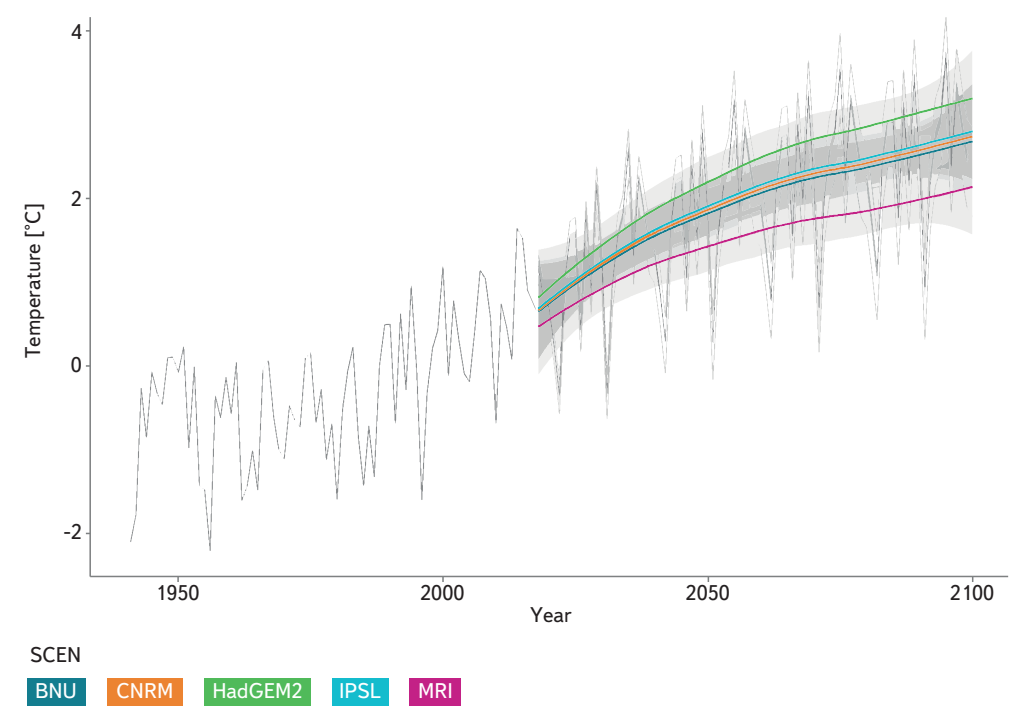

Fig. 4. Air temperature changes according to individual GCMs and RCP8.5 
Pro hodnocení vodohospodářské bilance byly vybrány scénáře:

1. $\mathbf{0}$ - označující současné podmínky

2. $\mathbf{2}$ - současné $\mathrm{klima}+2^{\circ} \mathrm{C}$

3. HadGEM2 - klima založené na výstupech GCM HadGEM2-ES RCP4.5

\section{Modelování hydrologické bilance}

K modelování hydrologické bilance byl použit model Bilan, který je vyvíjen více než 15 let v oddělení hydrologie Výzkumného ústavu vodohospodářského T. G. Masaryka, v. v. i. Model počítá v denním či měsičním časovém kroku chronologickou hydrologickou bilanci povodí či území. Vyjadřuje základní bilanční vztahy na povrchu povodí, v zóně aerace, do níž je zahrnut i vegetační kryt povodí, a v zóně podzemní vody. Jako ukazatel bilance energie, která hydrologickou bilanci významně ovlivňuje, je použita teplota vzduchu. Výpočtem se modeluje potenciální evapotranspirace, územní výpar, infiltrace do zóny aerace, průsak touto zónou, zásoba vody ve sněhu, zásoba vody v půdě a zásoba podzemní vody. Odtok je modelován jako součet tří složek: dvě složky prímého odtoku (zahrnující i hypodermický odtok) a základní odtok [7, 8, 9]. Pro modelování hydrologické bilance byla použita měsíční verze modelu.

\section{Hydrologické modelování změn klimatu}

Postup modelování dopadu změny klimatu na hydrologický režim (viz obr. 5) Ize stručně shrnout následovně:

1. Zvolený hydrologický model je pro vybrané povodí nakalibrován pomocí pozorovaných dat. Hydrologický model by měl být fyzikálně založen, aby bylo zaručeno, že i pro nepozorované podmínky bude poskytovat fyzikálně prijjatelné výsledky.

2. Vstupní veličiny z globálního, poprípadě vnořeného regionálního klimatického modelu jsou převedeny na scénářové řady pro jednotlivá povodí, a to:

a. statistickým downscalingem

b. „postprocessingem“ výstupu klimatického modelu, tj. využitím prírůstkové metody či korekce systematických chyb

Často je nutné pomocí prostorové interpolace vztáhnout data z výpočetních buněk klimatického modelu k těžišti daného povodí. Pro korektní využití všech metod (a-b) je nezbytné mít k dispozici pozorovaná data.

3. Pomocí nakalibrovaného hydrologického modelu a scénářových řad je provedena simulace hydrologické bilance pro scénářové období.

4. Modelované průtoky pro současnost a výhledová období jsou korigovány v jednotlivých měsících pomocí kvantilové metody [10].
The first model (NorESM1-M) represents a median of the ensemble of all GCMs. The MPI-ESM-LR + HadGEM2-ES models act as controlling GCMs for several Euro-CORDEX RCM simulations. This is after all true also for the selected median model, which also controls one of the Euro-CORDEX RCMs. The GISSE2-H + MRI-ESM1 models ensure meeting of the condition to cover inter-model variability and the CanESM2 + GFDL-CM3 models enable the last stated condition for the selection to be met. These models have been further tested for water management. Selected RCM models have also been tested. The HadGEM2-ES model has been chosen for the actual testing, which has thus been recommended in studies [6], recommending a median scenario of climate change impacts in water management. Fig. 4 presents temperature development pursuant to RCP8.5

The following scenarios have been selected to evaluate the water management balance:

1. $\mathbf{0}$ - current conditions

2. $\mathbf{2}$ - current climate $+2^{\circ} \mathrm{C}$

3. HadGEM2 - climate based on the outputs of GCM HadGEM2-ES RCP4.5

\section{Modelling of Hydrological Balance}

The Bilan model, which is being developed for over 15 years at the Hydrology Department of the T. G. Masaryk Water Research Institute, has been used for modelling hydrological balance. The model calculates in daily or monthly time steps chronological hydrological balance of a catchment area or of a territory. It expresses fundamental balance relations on the surface of the catchment area, in the aeration zone that also includes the vegetation cover of the catchment area, and in the groundwater zone. Air temperature is used as an energy balance indicator that has a significant impact on hydrological balance. The calculation models potential evapotranspiration, actual evaporation, infiltration into the aeration zone, seepage through this zone, snow water equivalent, water storage in the soil and groundwater storage. Runoff is modelled as a sum of three components: two components of direct runoff (that includes also hypodermic runoff) and base flow $[7,8,9]$. The monthly version of the model has been used for modelling hydrological balance.

\section{Hydrological Modelling of Climate Changes}

The procedure for modelling the climate change impact on the hydrological regime (see Fig. 5) may be concisely summarised as follows:

1. The chosen hydrological model is calibrated for selected catchment areas using observed data. The hydrological model should have a physical basis to make sure that it yields physically acceptable results also for unobserved conditions.

2. Input variables from a global or embedded regional climate model are transformed to scenario series for the individual catchment areas, namely by:

a. statistical downscaling

b. post-processing of the climate model output, i.e. by using the increment method or correction of systematic errors

It is often necessary to relate the data from calculation cells of the climate model to the centre of a given catchment area by spatial interpolation. It is essential to have observed data at one's disposal in order to use all methods (a-b) correctly. 


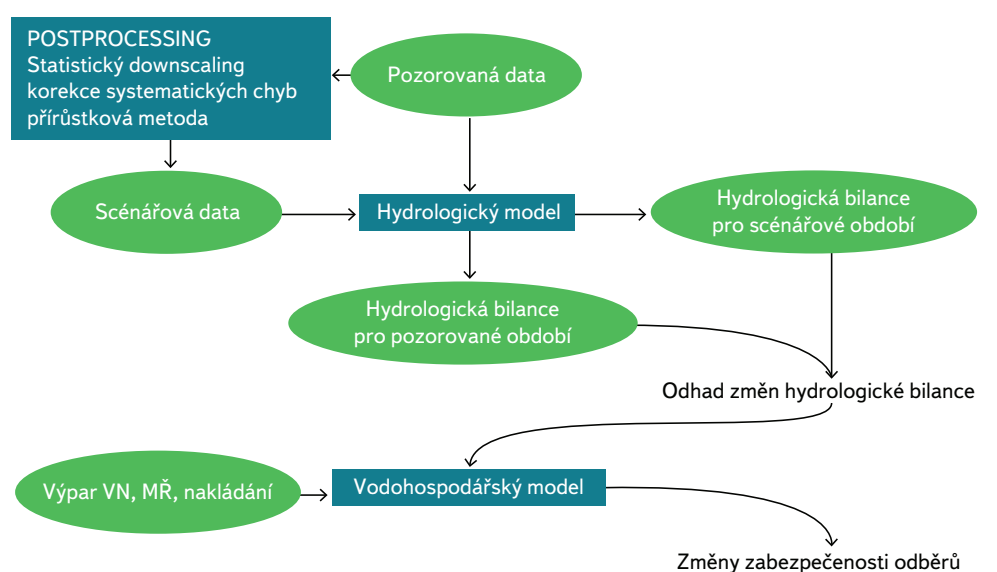

Obr. 5. Schéma hydrologického modelování dopadů změny klimatu

\section{Vodohospodářská bilance}

Na výše uvedené vyhodnocení dopadu klimatické změny na hydrologické charakteristiky navázalo posouzení zabezpečenosti odběrů vody pomocí metod vodohospodárské bilance a simulačního modelování zásobní funkce vodohospodářských soustav. Aplikovanou metodu podrobně popisuje [11], použité programové vybavení [12]. Simulační model simuluje chování soustavy $\checkmark$ chronologické řadě diskrétních časových kroků (zde zvolen měsíční krok) na základě znalosti časových řad přirozených průtoků (neovlivněných regulací a odběry/vypouštěním vody), požadavků na užívání vody (zde odběrů vody) a zachování minimálních průtoků, technických parametrů prvků soustavy (zde objemů zásobního prostoru nádrží a kapacit převodů vody) a do modelu zavedených pravidel regulace odtoku (manipulačních pravidel). Výstupem simulace jsou časové řady simulovaných aktivit: průtoků a výparu z hladin vodních nádrží, odběrů vody, odtoků z vodních nádrží, objemů vody a hladin v zásobním prostoru nádrží. Tyto časové řady jsou následně statisticky vyhodnoceny. Jako základní charakteristika vyjadřující zajištění odběrů vody je vyhodnocena zabezpečenost podle trvání $p_{t,}$ definovaná [13] (zjednodušeně vyjadřuje procentní podíl délky období, po kterou jsou požadavky na odběry vody a minimální průtoky plně zajištěny, z celkové délky celého posuzovaného období.)

Řešení bylo zpracováno variantně pro výše uvedené scénáře popisující současné podmínky a dopad klimatické změny. Časové řady přirozených průtoků a výparu v profilech vodních nádrží a míst odběrů vody byly výsledkem výše uvedeného modelování hydrologické bilance. Celková délka těchto řad byla 718 měsíců (tj. necelých 60 let). Požadavky na odběry vody byly posuzovány alternativně jako $v$ současnosti realizované odběry vody a jako povolené roční hodnoty odběrů. Jako současné odběry byly uvažovány maximální roční odběry vody evidované pro potřebu sestavení vodní bilance [1] za období let 2014-2019, a to jako během roku rovnoměrně rozdělené. Z údajů této evidence byly převzaty i povolené hodnoty odběrů, požadavky na minimální průtoky pod vodními nádržemi a objemy zásobního prostoru vodních nádrží. Do řešení byl započitán i vliv prípadných dalších skutečných odběrů a vypouštění vody v povodí vodních nádrží a další relevantní požadavky na zajištění odběrů pro prưmysl (např. vodní nádrže Slezská Harta, Kružberk, Morávka a Šance) či zemědělství (např. vodní nádrže Vír I, Vranov a Znojmo). Zajištění požadavků na vodárenské odběry bylo vždy (tj. v každém časovém kroku simulace) uvažováno jako přednostní oproti jiným požadavkům na vodní zdroje, včetně požadavků na minimální průtoky pod vodními nádržemi. Vzhledem k tomu, že se jednalo o modelování možné budoucí situace, nebyla uvažována současná pravidla pro dispečerská řízení vodních nádrží (jsou nastavena na stávající hydrologické podmínky a změna těchto podmínek by si vynutila jejich revizi a optimalizaci).

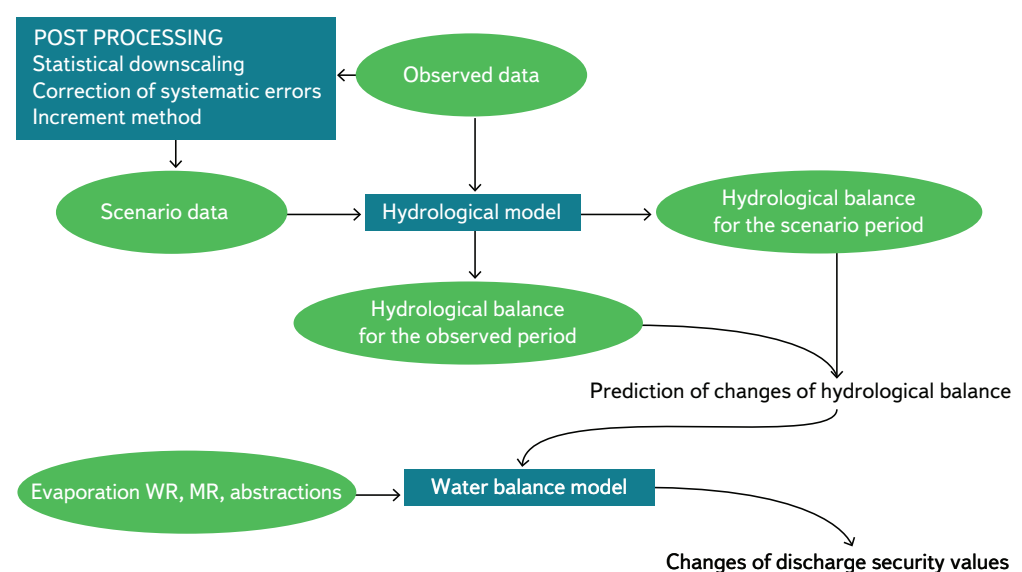

Fig. 5. Scheme of hydrological modelling of climate change impacts

3. Simulation of hydrological balance for the scenario period is done using a calibrated hydrological model and scenario series.

4. Modelled discharge for the present and future periods are adjusted in the individual months using the quantile method [10].

\section{Water Balance}

The above evaluation of the climate change impact on hydrological characteristics has been followed by an assessment of the security of water demand with the help of the water balance method and simulation modelling of the storage function of water resources and supply systems. The applied method is described in detail [11] as well as the software used [12]. The simulation model simulates behaviour of the system in a chronological series of discrete time steps (the monthly time step has been selected in this case) based on the knowledge of time series of natural discharges (unaffected by regulation and water abstraction/release), requirements for water use (water demand in this case) and maintenance of minimum discharges, technical parameters of the respective elements of the system (volume of the storage space of water reservoirs and water transfer capacity) and a model containing introduced rules of runoff regulation (handling rules).Time series of simulated activities are an output of the simulation: discharge and evaporation from the surface of water reservoirs, water demand, runoff from water reservoirs, water volume and water levels in the storage space of reservoirs. These time series are subsequently statistically evaluated. Security according to the duration of $p_{t}$ defined in [13] has been evaluated as fundamental characteristics that expresses the security of water demand (to put it simply, it expresses a percentage share of the duration of a period during which water demand and minimum discharge requirements are secured out of the whole duration of the total assessed period.)

Alternatives have been prepared for the above scenarios that describe current conditions and the climate change impact. The aforementioned modelling of hydrological balance has yielded time series of natural discharges and evaporation in the profiles of water reservoirs and water abstraction sites. The overall length of these series has been 718 months (i.e. less than 60 years). Water demand requirements have been assessed alternatively as water demand currently in place and as permitted annual demand values. Maximum annual water demand recorded for compiling the water balance between 2014 and 2019 has been considered as current demand, evenly distributed throughout the year [1]. Permitted demand values, minimum discharge requirements downstream from water reservoirs and storage space volume of water reservoirs have been taken from data contained in the above records. Impact of potential other 


\section{VÝSLEDKY}

Výsledkem výše popsaného postupu řešení byla kvantifikace možných dopadů klimatické změny na hydrologické charakteristiky (průtoky a výpar z vodní hladiny a evapotranspirace krajiny) a následné vyhodnocení zabezpečenosti vodárenských odběrů zajištovaných vodními nádržemi v těchto podmínkách. Na obr. 6 jsou uvedeny změny přirozených odtoků (scénář/současnost) pro scénáře 2 a HadGEM formou grafu typu boxplot².

Výsledky vyhodnocení zabezpečenosti vodárenských odběrů jsou - prostřednictvím hodnoty zabezpečenosti podle trvání $p_{t}-$ uvedeny v tab. 1 a ilustrovány na obr. 7. Pro snadnější orientaci jsou odběry podle dosažené zabezpečenosti rozděleny do čtyř skupin a označeny pomocí barevné škály, a to následujícím způsobem: (a) modře jsou označeny odběry vody s bezporuchovou $\left(\mathrm{tj} . p_{\mathrm{t}}=99,9\right)$ zabezpečeností současných i povolených odběrů ve všech hodnocených scénárích; (b) zeleně jsou označeny středně rizikové odběry $s$ bezporuchovou zabezpečeností pouze současných odběrů ve všech hodnocených scénárích; (c) žlutě jsou označeny odběry s bezporuchovou zabezpečeností současných odběrů pouze v př́znivějším scénáři dopadu klimatické změny HadGEM2 a (d) červeně jsou jako vysoce rizikové označeny odběry, kde bezporuchová zabezpečenost není dosažena ani v jednom ze scénářu dopadu klimatické změny.

Jako vysoce rizikové vzhledem k zajištění odběrů vody v podmínkách klimatické změny byly vyhodnoceny vodní nádrže Stanovice, Žlutice, Pilská, Obecnice, Opatovice, Bojkovice, Mariánské Lázně - Podhora, Klíčava a Nová Říše. Jako středně rizikové byly vyhodnoceny vodní nádrže Vranov - Znojmo, Vrchlice, Slušovice, Koryčany a Ludkovice. Naopak bezproblémové zajištění současných i povolených odběrů vody bylo vyhodnoceno u vodních nádrží Římov, Nýrsko, Horka, Lučina, Slezská Harta - Kružberk, Seč - Křižanovice, Jirkov, Myslivny, Josefưv Důl, Souš, Mostiště, Hubenov a Landštejn.

Obr. 8 ilustruje efekt využití akumulace vody v zásobním prostoru vodních nádrží na zajištění současných požadavků na vodárenské odběry a minimální průtoky ve vodních tocích pod nádržemi. Vyjádřen je podíl objemu těchto požadavků, který může být zajištěn pouze prítokem v profilu vodní nádrže, a podíl, který může být zajištěn pouze s pomocí akumulace vody v zásobním prostoru. Vyhodnocení je zpracováno z celé délky časové řady simulace pro vodní nádrže s objemem zásobního prostoru větším než 10 mil. $\mathrm{m}^{3}$. Vzhledem $\mathrm{k}$ simulaci zásobní funkce $v$ měsíčním kroku (kdy jsou uvažovány průměrné měsíční průtoky), je zde zanedbán vliv rozkolísanosti průtoku v průběhu jednotlivých měsíců.
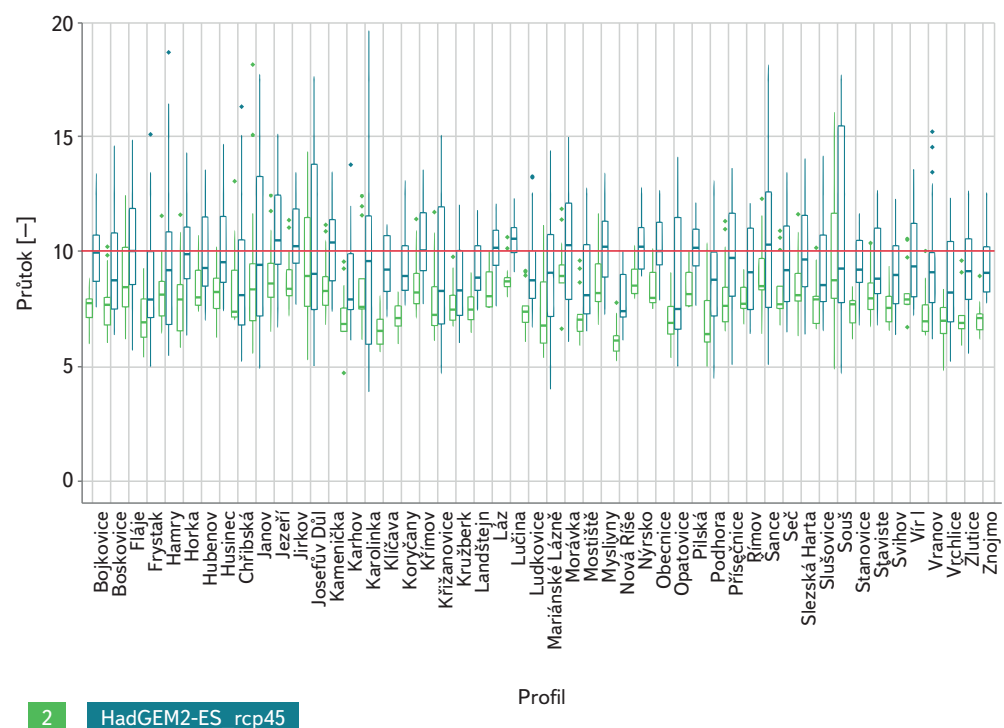

Profil

Obr. 6. Snižení odtoku z povodí vodárenských nádrží actual demand and water release in the catchment area of water reservoirs as well as further relevant requirements for the security of water demand for the industry (e.g. water reservoirs Slezská Harta, Kružberk, Morávka and Šance) or agriculture (e.g. water reservoirs Vír I, Vranov and Znojmo). The security of requirements for drinking water demand has always (i.e. in each time step of the simulation) been considered as a priority compared to other requirements for water resources, including requirements for minimum discharges downstream from the water reservoirs. Due to the fact that a potential future situation has been modelled, current operating rules for water reservoirs have not been considered (they have been set with the existing hydrological conditions in mind and a change of these conditions would necessitate their review and optimisation).

\section{RESULTS}

The aforementioned procedure has resulted in a quantification of potential climate change impacts on hydrological characteristics (discharges and evaporation from the water surface and evapotranspiration of the landscape) and subsequent evaluation of the security drinking water demand provided for by water reservoirs in these conditions. Fig. 6 presents changes of natural runoffs (scenario/the present) for scenario 2 and for the HadGEM scenario in the form of a boxplot? ${ }^{2}$.

Results of the evaluation of the security of drinking water demand are presented in Tab. 1 and are illustrated in Fig. 7 by the security value according to the duration of $\mathrm{p}_{\mathrm{t}}$. In order to make the presentation more straightforward, water demand has been divided according to achieved security into four groups and has been colour-marked in the following way: (a) the blue colour marks water demand with trouble-free (i.e. $\left.p_{t}=99,9\right)$ security of current and permitted demand in all evaluated scenarios; (b) the green colour marks demand with a medium risk with trouble-free security only of current demand in all evaluated scenarios; (c) the yellow colour marks demand with trouble-free security of current demand only in the more favourable HadGEM2 scenario of the climate change impact and (d) the red colour marks demand with a high risk, i.e. where trouble-free security is not ensured in any of the scenarios of the climate change impact.

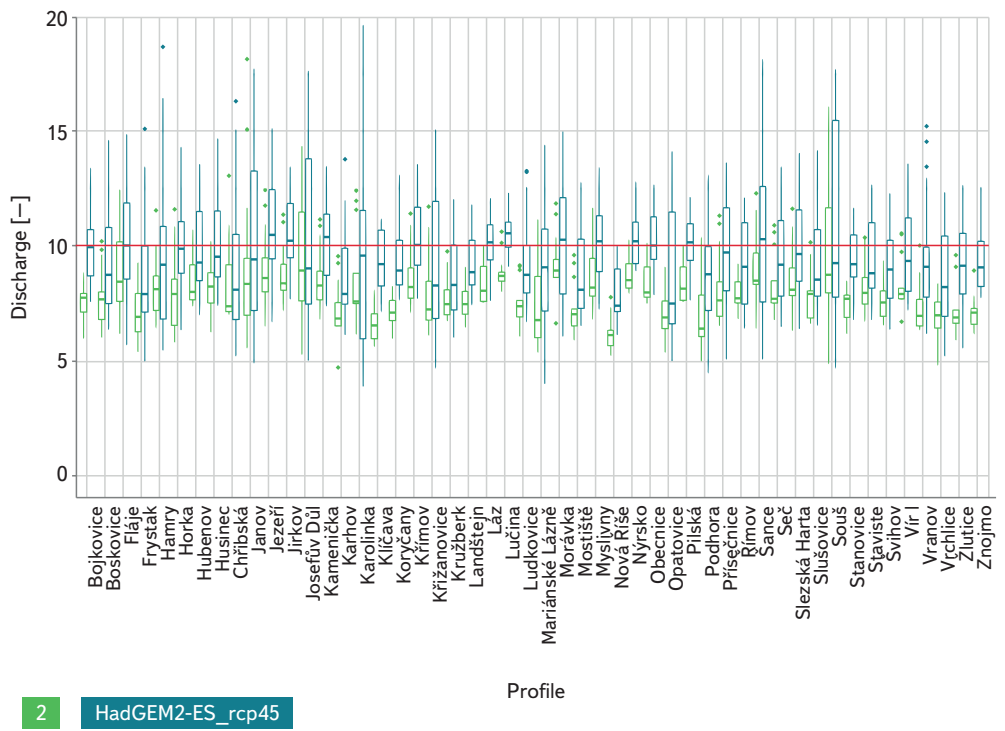

Fig. 6. Reduction in runoff from the catchment area of water reservoirs 


\begin{tabular}{|c|c|c|c|c|c|c|c|c|}
\hline \multirow{3}{*}{ Vodní nádrž } & \multirow{3}{*}{$\begin{array}{l}\text { Objem } \\
\text { zásob. } \\
\text { prostoru } \\
\text { [mil.m³] }\end{array}$} & \multirow{3}{*}{$\begin{array}{l}\text { Úpravna } \\
\text { vody }\end{array}$} & \multirow{3}{*}{$\begin{array}{l}\text { Skutečný } \\
\text { roční } \\
\text { odběr } \\
\text { [tis.m³] }\end{array}$} & \multirow{3}{*}{$\begin{array}{l}\text { Povolený } \\
\text { roční } \\
\text { odběr } \\
{\left[\text { tis.m }{ }^{3}\right]}\end{array}$} & \multicolumn{4}{|c|}{$\begin{array}{l}\text { Varianta hydrologických podmínek } \\
\text { a požadavků na odběry }\end{array}$} \\
\hline & & & & & $\begin{array}{l}\text { „0“ } \\
\text { současné } \\
\text { odběry }\end{array}$ & $\begin{array}{l}\text { HadGEM2 } \\
\text { současné } \\
\text { odběry }\end{array}$ & $\begin{array}{l}\text { "2“ } \\
\text { současné } \\
\text { odběry }\end{array}$ & $\begin{array}{l}\text { HadGEM2 } \\
\text { povolené } \\
\text { odběry }\end{array}$ \\
\hline & & & & & \multicolumn{4}{|c|}{ Zabezpečenost podle trvání $p_{t}[\%]$} \\
\hline Bojkovice & 0,770 & Bojkovice & 546 & 1200 & 93,1 & 91,8 & 83,3 & 80,7 \\
\hline \multirow{2}{*}{ Fláje } & \multirow{2}{*}{19,500} & Meziboří & 12119 & 14000 & 99,9 & 99,9 & 99,9 & 98,7 \\
\hline & & Litvínov-Šumná & 2524 & 5800 & 99,9 & 99,9 & 99,9 & 98,7 \\
\hline Hamry & 1,206 & Hamry & 452 & 1600 & 99,9 & 99,8 & 99,8 & 98,1 \\
\hline Horka & 16,539 & Horka & 3185 & 5110 & 99,9 & 99,9 & 99,9 & 99,9 \\
\hline Hubenov & 2,395 & Hosov & 3984 & 4446 & 99,9 & 99,9 & 99,9 & 99,9 \\
\hline Chřibská & 0,839 & Chřibská & 481 & 1250 & 99,9 & 99,9 & 99,9 & 98,2 \\
\hline Jirkov & 1,917 & Jirkov & 1082 & 2700 & 99,9 & 99,9 & 99,9 & 99,9 \\
\hline Josefův Důl & 19,133 & Bedřichov & 5427 & 9000 & 99,9 & 99,9 & 99,9 & 99,9 \\
\hline Kamenička & 0,594 & III. Mlýn & 984 & 2000 & 99,9 & 99,9 & 99,9 & 96,8 \\
\hline Krímov & 1,260 & III. Mlýn & 2205 & 3000 & 99,9 & 99,9 & 99,9 & 96,8 \\
\hline Karhov & 0,288 & \multirow{2}{*}{$\begin{array}{l}\text { Studená-Horní } \\
\text { Pole }\end{array}$} & \multirow{2}{*}{237} & \multirow{2}{*}{400} & \multirow[b]{2}{*}{99,9} & \multirow{2}{*}{99,1} & \multirow{2}{*}{95,9} & \multirow{2}{*}{96,1} \\
\hline Zhejral & 0,157 & & & & & & & \\
\hline Karolinka & 5,813 & Karolinka & 4200 & 7884 & 99,9 & 99,9 & 99,9 & 99,3 \\
\hline Klíčava & 7,860 & Klíčava & 2333 & 3469 & 98,9 & 98,1 & 95,4 & 95,2 \\
\hline Koryčany & 2,130 & Koryčany & 942 & 1450 & 99,9 & 99,9 & 98,5 & 97,4 \\
\hline Kružberk & 24,580 & Podhradí & 34537 & 85147 & 99,9 & 99,9 & 99,9 & 99,9 \\
\hline Slezská Harta & 182,010 & Leskovec & 869 & 3154 & 99,9 & 99,9 & 99,9 & 99,9 \\
\hline Křižanovice & 1,620 & Monaco & 3679 & 6500 & 99,9 & 99,9 & 99,9 & 99,9 \\
\hline Seč & 14,017 & Seč & 202 & 350 & 99,9 & 99,9 & 99,9 & 99,9 \\
\hline Landštejn & 2,590 & Landštejn & 753 & 1200 & 99,9 & 99,9 & 99,9 & 99,9 \\
\hline Láz & 0,820 & Kozičín & 741 & 1113 & 99,9 & 99,9 & 99,8 & 98,9 \\
\hline \multirow{2}{*}{ Lučina } & \multirow{2}{*}{3,457} & Milíkov & 1035 & 1500 & 99,9 & 99,9 & 99,9 & 99,9 \\
\hline & & Svobodka & 1347 & 2500 & 99,9 & 99,9 & 99,9 & 99,9 \\
\hline Ludkovice & 0,498 & Ludkovice & 479 & 772 & 99,9 & 99,9 & 99,8 & 99,5 \\
\hline
\end{tabular}




\begin{tabular}{|c|c|c|c|c|c|c|c|c|}
\hline \multirow{3}{*}{ Vodní nádrž } & \multirow{3}{*}{$\begin{array}{l}\text { Objem } \\
\text { zásob. } \\
\text { prostoru } \\
{\left[\mathrm{mil}^{3} \mathrm{~m}^{3}\right]}\end{array}$} & \multirow{3}{*}{$\begin{array}{l}\text { Úpravna } \\
\text { vody }\end{array}$} & \multirow{3}{*}{$\begin{array}{l}\text { Skutečný } \\
\text { roční } \\
\text { odběr } \\
\text { [tis.m³] }\end{array}$} & \multirow{3}{*}{$\begin{array}{l}\text { Povolený } \\
\text { roční } \\
\text { odběr } \\
{[\text { tis.m³] }}\end{array}$} & \multicolumn{4}{|c|}{$\begin{array}{l}\text { Varianta hydrologických podmínek } \\
\text { a požadavků na odběry }\end{array}$} \\
\hline & & & & & $\begin{array}{l}\text { "0“ } \\
\text { současné } \\
\text { odběry }\end{array}$ & $\begin{array}{l}\text { HadGEM2 } \\
\text { současné } \\
\text { odběry }\end{array}$ & $\begin{array}{l}\text { "2“ } \\
\text { současné } \\
\text { odběry }\end{array}$ & $\begin{array}{l}\text { HadGEM2 } \\
\text { povolené } \\
\text { odběry }\end{array}$ \\
\hline & & & & & \multicolumn{4}{|c|}{ Zabezpečenost podle trvání $p_{t}[\%]$} \\
\hline Mariánské Lázně & 0,211 & \multirow{2}{*}{$\begin{array}{l}\text { Mariánské } \\
\text { Lázně }\end{array}$} & \multirow{2}{*}{725} & \multirow{2}{*}{1200} & \multirow{2}{*}{99,9} & \multirow{2}{*}{98,5} & \multirow{2}{*}{97,8} & \multirow{2}{*}{96,0} \\
\hline Podhora & 2,041 & & & & & & & \\
\hline Morávka* & 4,960 & Vyšní Lhoty & 6139 & 14500 & 99,9 & 99,9 & 99,9 & 95,4 \\
\hline Šance* & 39,960 & $\begin{array}{l}\text { Nová Ves } \\
\text { u Frýdlantu }\end{array}$ & 25415 & 69379 & 99,9 & 99,9 & 99,9 & 95,4 \\
\hline Mostiště & 9,339 & Mostiště & 3183 & 6300 & 99,9 & 99,9 & 99,9 & 99,9 \\
\hline Myslivny & 0,036 & Myslivny & 284 & 694 & 99,9 & 99,9 & 99,9 & 99,9 \\
\hline Nová Říše & 2,237 & Nová Ř́íse & 1038 & 2523 & 96,3 & 88,9 & 79,4 & 55,8 \\
\hline \multirow{2}{*}{ Nýrsko } & \multirow{2}{*}{15,966} & Klatovy & 3253 & 4500 & 99,9 & 99,9 & 99,9 & 99,9 \\
\hline & & Plzeň & 14125 & 16500 & 99,9 & 99,9 & 99,9 & 98,9 \\
\hline Obecnice & 0,547 & Hvězdička & 972 & 1662 & 99,9 & 99,6 & 98,9 & 96,0 \\
\hline Opatovice & 7,784 & Lhota & 2010 & 3784 & 99,3 & 98,5 & 96,7 & 89,0 \\
\hline Pilská & 1,306 & Kozičín & 1085 & 1142 & 99,6 & 99,3 & 98,4 & 99,1 \\
\hline Přísečnice & 46,670 & Hradiště & 15699 & 30300 & 99,9 & 99,9 & 99,9 & 78,6 \\
\hline Římov & 30,016 & Plav & 17175 & 34600 & 99,9 & 99,9 & 99,9 & 99,9 \\
\hline Slušovice & 7,245 & Klečůvka & 5080 & 7128 & 99,9 & 99,9 & 99,1 & 97,8 \\
\hline Souš & 4,621 & Souš & 5156 & 7000 & 99,9 & 99,9 & 99,9 & 99,9 \\
\hline Stanovice & 20,164 & Březová & 7059 & 12614 & 99,9 & 99,6 & 96,0 & 84,0 \\
\hline Švihov & 246,068 & Želivka & 93291 & 165600 & 99,9 & 99,9 & 99,9 & 94,9 \\
\hline \multirow{2}{*}{ Vír I } & \multirow{2}{*}{44,056} & Vír & 1244 & 3150 & 99,9 & 99,9 & 99,9 & 99,3 \\
\hline & & Švařec & 7688 & 56765 & 99,9 & 99,9 & 99,9 & 99,3 \\
\hline Vranov & 79,668 & Štítary & 3019 & 4200 & 99,9 & 99,9 & 99,1 & 99,9 \\
\hline Vrchlice & 7,890 & Trojice & 3677 & 7884 & 99,9 & 99,8 & 92,2 & 85,7 \\
\hline Znojmo & 2,450 & Znojmo & 2668 & 4730 & 99,9 & 99,9 & 98,1 & 99,6 \\
\hline Žlutice & 10,281 & Žlutice & 2650 & 4730 & 99,9 & 98,8 & 98,0 & 97,4 \\
\hline
\end{tabular}

* Prí uvažování vzájemné zastupitelnosti vodních nádrži Morávka a Šance 

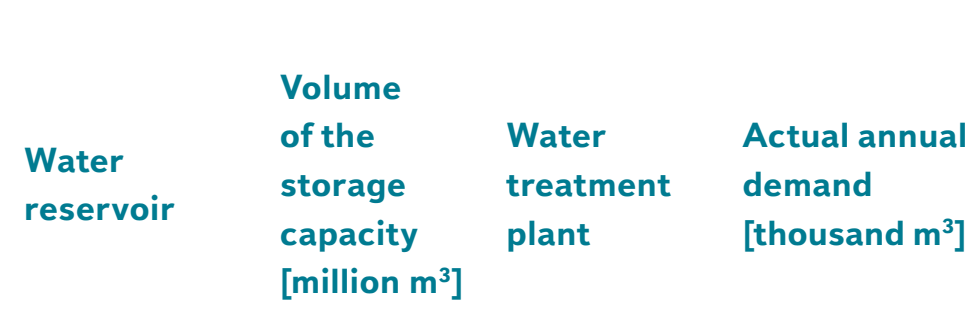

\begin{tabular}{lllll} 
& \multicolumn{4}{l}{$\begin{array}{l}\text { Alternative of hydrological conditions and } \\
\text { water abstraction requirements }\end{array}$} \\
\cline { 2 - 4 } $\begin{array}{l}\text { Permitted } \\
\text { annual }\end{array}$ & "0" & HadGEM2 & "2" & HadGEM2 \\
demand & Current & Current & Current & Permitted \\
[thousand m $^{3}$ ] & demand & demand & demand & demand \\
\cline { 2 - 4 } & & &
\end{tabular}

\begin{tabular}{|c|c|c|c|c|c|c|c|c|}
\hline Bojkovice & 0,770 & Bojkovice & 546 & 1200 & 93,1 & 91,8 & 83,3 & 80,7 \\
\hline \multirow{2}{*}{ Fláje } & \multirow{2}{*}{19,500} & Meziboří & 12119 & 14000 & 99,9 & 99,9 & 99,9 & 98,7 \\
\hline & & Litvínov-Šumná & 2524 & 5800 & 99,9 & 99,9 & 99,9 & 98,7 \\
\hline Hamry & 1,206 & Hamry & 452 & 1600 & 99,9 & 99,8 & 99,8 & 98,1 \\
\hline Horka & 16,539 & Horka & 3185 & 5110 & 99,9 & 99,9 & 99,9 & 99,9 \\
\hline Hubenov & 2,395 & Hosov & 3984 & 4446 & 99,9 & 99,9 & 99,9 & 99,9 \\
\hline Chřibská & 0,839 & Chřibská & 481 & 1250 & 99,9 & 99,9 & 99,9 & 98,2 \\
\hline Jirkov & 1,917 & Jirkov & 1082 & 2700 & 99,9 & 99,9 & 99,9 & 99,9 \\
\hline Josefův Důl & 19,133 & Bedřichov & 5427 & 9000 & 99,9 & 99,9 & 99,9 & 99,9 \\
\hline Kamenička & 0,594 & III. Mlýn & 984 & 2000 & 99,9 & 99,9 & 99,9 & 96,8 \\
\hline Krímov & 1,260 & III. Mlýn & 2205 & 3000 & 99,9 & 99,9 & 99,9 & 96,8 \\
\hline Karhov & 0,288 & \multirow{2}{*}{$\begin{array}{l}\text { Studená-Horní } \\
\text { Pole }\end{array}$} & \multirow[b]{2}{*}{237} & \multirow[b]{2}{*}{400} & \multirow[b]{2}{*}{99,9} & \multirow[b]{2}{*}{99,1} & \multirow[b]{2}{*}{95,9} & \multirow[b]{2}{*}{96,1} \\
\hline Zhejral & 0,157 & & & & & & & \\
\hline Karolinka & 5,813 & Karolinka & 4200 & 7884 & 99,9 & 99,9 & 99,9 & 99,3 \\
\hline Klíčava & 7,860 & Klíčava & 2333 & 3469 & 98,9 & 98,1 & 95,4 & 95,2 \\
\hline Koryčany & 2,130 & Koryčany & 942 & 1450 & 99,9 & 99,9 & 98,5 & 97,4 \\
\hline Kružberk & 24,580 & Podhradí & 34537 & 85147 & 99,9 & 99,9 & 99,9 & 99,9 \\
\hline Slezská Harta & 182,010 & Leskovec & 869 & 3154 & 99,9 & 99,9 & 99,9 & 99,9 \\
\hline Křižanovice & 1,620 & Monaco & 3679 & 6500 & 99,9 & 99,9 & 99,9 & 99,9 \\
\hline Seč & 14,017 & Seč & 202 & 350 & 99,9 & 99,9 & 99,9 & 99,9 \\
\hline Landštejn & 2,590 & Landštejn & 753 & 1200 & 99,9 & 99,9 & 99,9 & 99,9 \\
\hline Láz & 0,820 & Kozičín & 741 & 1113 & 99,9 & 99,9 & 99,8 & 98,9 \\
\hline \multirow{2}{*}{ Lučina } & \multirow{2}{*}{3,457} & Milíkov & 1035 & 1500 & 99,9 & 99,9 & 99,9 & 99,9 \\
\hline & & Svobodka & 1347 & 2500 & 99,9 & 99,9 & 99,9 & 99,9 \\
\hline Ludkovice & 0,498 & Ludkovice & 479 & 772 & 99,9 & 99,9 & 99,8 & 99,5 \\
\hline
\end{tabular}




\begin{tabular}{|c|c|c|c|c|c|c|c|c|}
\hline \multirow{3}{*}{$\begin{array}{l}\text { Water } \\
\text { reservoir }\end{array}$} & \multirow{3}{*}{$\begin{array}{l}\text { Volume } \\
\text { of the } \\
\text { storage } \\
\text { capacity } \\
\text { [million } \mathrm{m}^{3} \text { ] }\end{array}$} & \multirow{3}{*}{$\begin{array}{l}\text { Water } \\
\text { treatment } \\
\text { plant }\end{array}$} & \multirow{3}{*}{$\begin{array}{l}\text { Actual annual } \\
\text { demand } \\
\text { [thousand } \mathrm{m}^{3} \text { ] }\end{array}$} & \multirow{3}{*}{$\begin{array}{l}\text { Permitted } \\
\text { annual } \\
\text { demand } \\
\text { [thousand } \mathrm{m}^{3} \text { ] }\end{array}$} & \multicolumn{4}{|c|}{$\begin{array}{l}\text { Alternative of hydrological conditions and } \\
\text { water abstraction requirements }\end{array}$} \\
\hline & & & & & $\begin{array}{l}\text { “0" } \\
\text { Current } \\
\text { demand }\end{array}$ & $\begin{array}{l}\text { HadGEM2 } \\
\text { Current } \\
\text { demand }\end{array}$ & $\begin{array}{l}\text { "2" } \\
\text { Current } \\
\text { demand }\end{array}$ & $\begin{array}{l}\text { HadGEM2 } \\
\text { Permitted } \\
\text { demand }\end{array}$ \\
\hline & & & & & \multicolumn{4}{|c|}{ Security according to the duration of $p_{t}(\%)$} \\
\hline Mariánské Lázně & 0,211 & \multirow{2}{*}{$\begin{array}{l}\text { Mariánské } \\
\text { Lázně }\end{array}$} & \multirow{2}{*}{725} & \multirow{2}{*}{1200} & \multirow{2}{*}{99,9} & \multirow{2}{*}{98,5} & \multirow{2}{*}{97,8} & \multirow{2}{*}{96,0} \\
\hline Podhora & 2,041 & & & & & & & \\
\hline Morávka* & 4,960 & Vyšní Lhoty & 6139 & 14500 & 99,9 & 99,9 & 99,9 & 95,4 \\
\hline Šance ${ }^{*}$ & 39,960 & $\begin{array}{l}\text { Nová Ves } \\
\text { u Frýdlantu }\end{array}$ & 25415 & 69379 & 99,9 & 99,9 & 99,9 & 95,4 \\
\hline Mostiště & 9,339 & Mostiště & 3183 & 6300 & 99,9 & 99,9 & 99,9 & 99,9 \\
\hline Myslivny & 0,036 & Myslivny & 284 & 694 & 99,9 & 99,9 & 99,9 & 99,9 \\
\hline Nová Říše & 2,237 & Nová Říše & 1038 & 2523 & 96,3 & 88,9 & 79,4 & 55,8 \\
\hline \multirow{2}{*}{ Nýrsko } & \multirow{2}{*}{15,966} & Klatovy & 3253 & 4500 & 99,9 & 99,9 & 99,9 & 99,9 \\
\hline & & Plzeň & 14125 & 16500 & 99,9 & 99,9 & 99,9 & 98,9 \\
\hline Obecnice & 0,547 & Hvězdička & 972 & 1662 & 99,9 & 99,6 & 98,9 & 96,0 \\
\hline Opatovice & 7,784 & Lhota & 2010 & 3784 & 99,3 & 98,5 & 96,7 & 89,0 \\
\hline Pilská & 1,306 & Kozičín & 1085 & 1142 & 99,6 & 99,3 & 98,4 & 99,1 \\
\hline Přísečnice & 46,670 & Hradiště & 15699 & 30300 & 99,9 & 99,9 & 99,9 & 78,6 \\
\hline Římov & 30,016 & Plav & 17175 & 34600 & 99,9 & 99,9 & 99,9 & 99,9 \\
\hline Slušovice & 7,245 & Klečůvka & 5080 & 7128 & 99,9 & 99,9 & 99,1 & 97,8 \\
\hline Souš & 4,621 & Souš & 5156 & 7000 & 99,9 & 99,9 & 99,9 & 99,9 \\
\hline Stanovice & 20,164 & Březová & 7059 & 12614 & 99,9 & 99,6 & 96,0 & 84,0 \\
\hline Švihov & 246,068 & Želivka & 93291 & 165600 & 99,9 & 99,9 & 99,9 & 94,9 \\
\hline \multirow{2}{*}{ Vír l } & \multirow{2}{*}{44,056} & Vír & 1244 & 3150 & 99,9 & 99,9 & 99,9 & 99,3 \\
\hline & & Švařec & 7688 & 56765 & 99,9 & 99,9 & 99,9 & 99,3 \\
\hline Vranov & 79,668 & Štítary & 3019 & 4200 & 99,9 & 99,9 & 99,1 & 99,9 \\
\hline Vrchlice & 7,890 & Trojice & 3677 & 7884 & 99,9 & 99,8 & 92,2 & 85,7 \\
\hline Znojmo & 2,450 & Znojmo & 2668 & 4730 & 99,9 & 99,9 & 98,1 & 99,6 \\
\hline Žlutice & 10,281 & Žlutice & 2650 & 4730 & 99,9 & 98,8 & 98,0 & 97,4 \\
\hline
\end{tabular}

* Considering the mutual replaceability of Morávka and Šance water reservoirs 
Současný ročni odbèr

- Do 1000 [th, m']

(2) 1000-10000 [tis. m']

vetsi neż 10000 [tis. m']

\section{Zabezpeđenost odbēri}

- Bez rizika zabezpeleni soúlasmých i povolených odberù

- Bez rizila zabezpexeni soulasnjych odbernó

- Stredni riziko zabezpecteni soukasnjych odbiri

- Vysoke riziko zabezpedeni soulasných odbirù

\section{Povodi vodnich nadirt}

Snilteni mediánu odtobu ve scenâ

HadGEM2 oproti soućusnosti (scénar "0")

\begin{tabular}{|c|c|c|}
\hline Bez snibeni pritroku & $\longrightarrow$ & Statni hranice \\
\hline Pod $10 \%$ & $\sim$ & Vodni tok \\
\hline $10-20 \%$ & & DiBS povod I' \\
\hline $20-30 \%$ & & Kral \\
\hline Vice nez $30 \%$ & 불 & Sidla \\
\hline
\end{tabular}

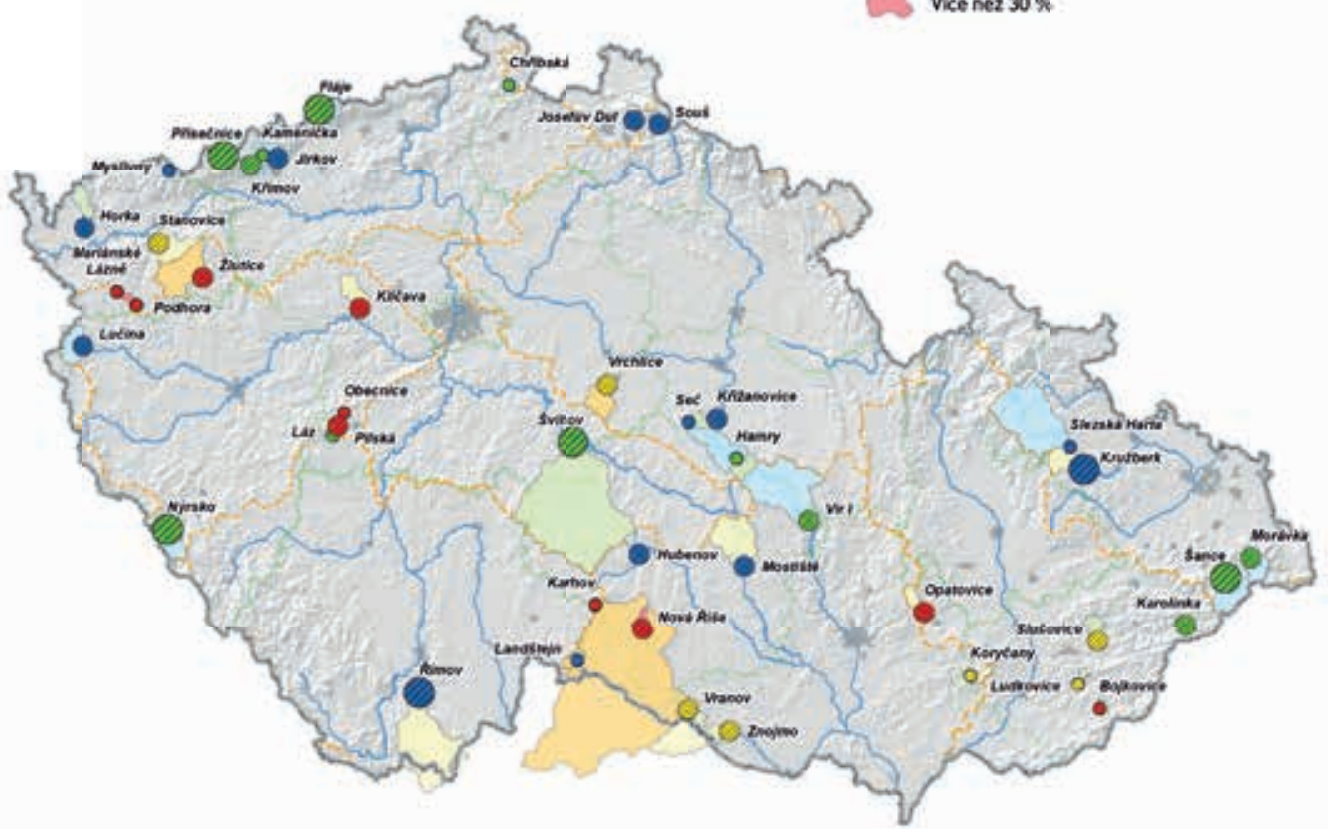

Obr. 7. Riziko nedostatečného zajištění požadavků na vodárenské odběry v podmínkách klimatické změny

Water reservoirs with drinking water demand

\section{Current annual demand}

Up to 1,000 [thousand $m^{\prime}$ ]

(2) $1,000-10,000$ [thousand $m^{\prime}$ ']

More than 10,000 [thousand $\mathrm{m}^{\prime}$ ]
Water reservoirs with drinking water demand

\section{Security of demand}

- Without a risk of security current and permitted demand

- Without a risk of security current demand

- Medium risk of security current demand

- High risk of security current demand

\section{Catchment area of water reservoirs}

Reduction in the median runolf in the HadGEM2 scenario in comparison to the present (scenario " 0 ")

[-3. Without a reduction in discharge

(1) Under $10 \%$

[17) $10-20 \%$

C.3 $20-30 \%$

Q.3 More than $30 \%$

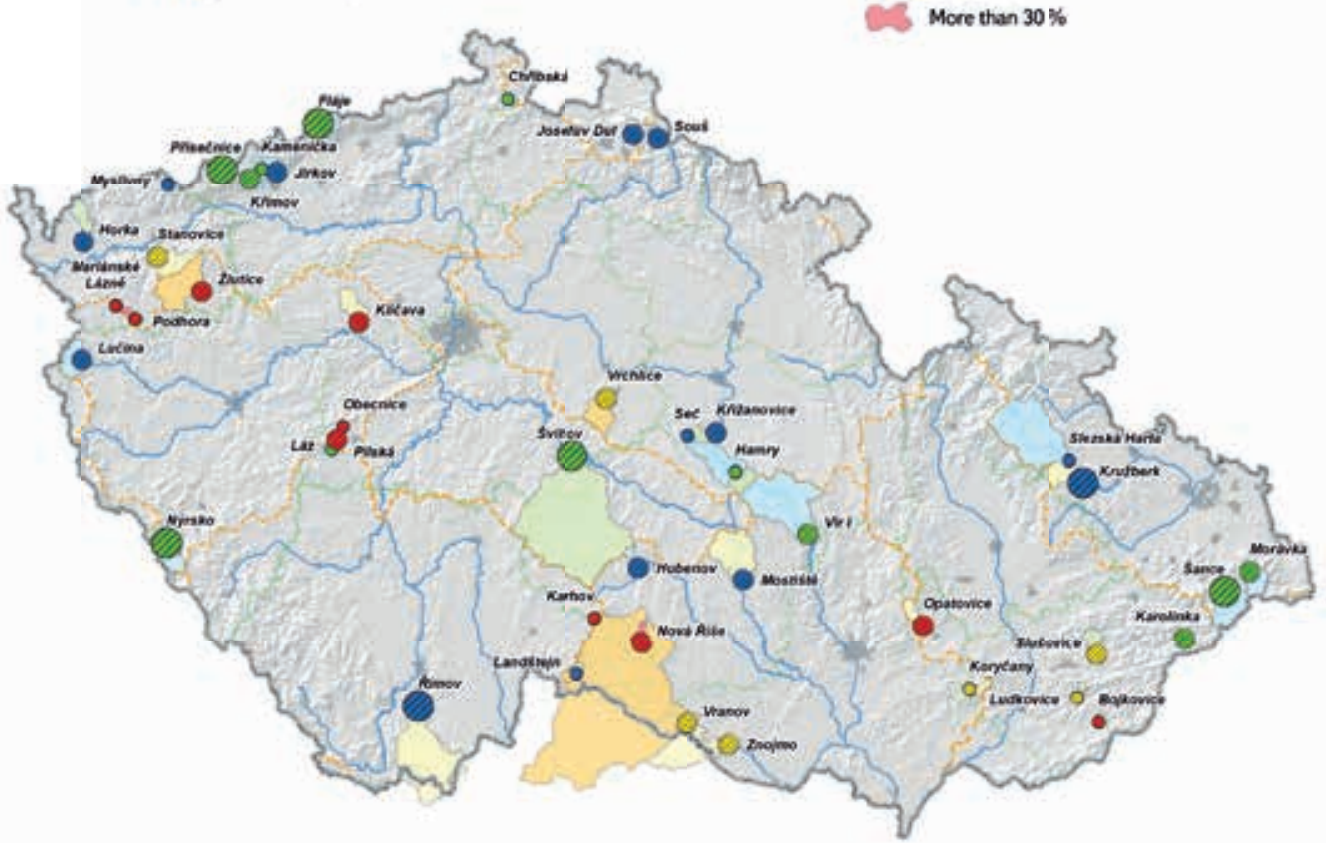

State torder

An- Watercourse Sub-cachment area Region Settiements 


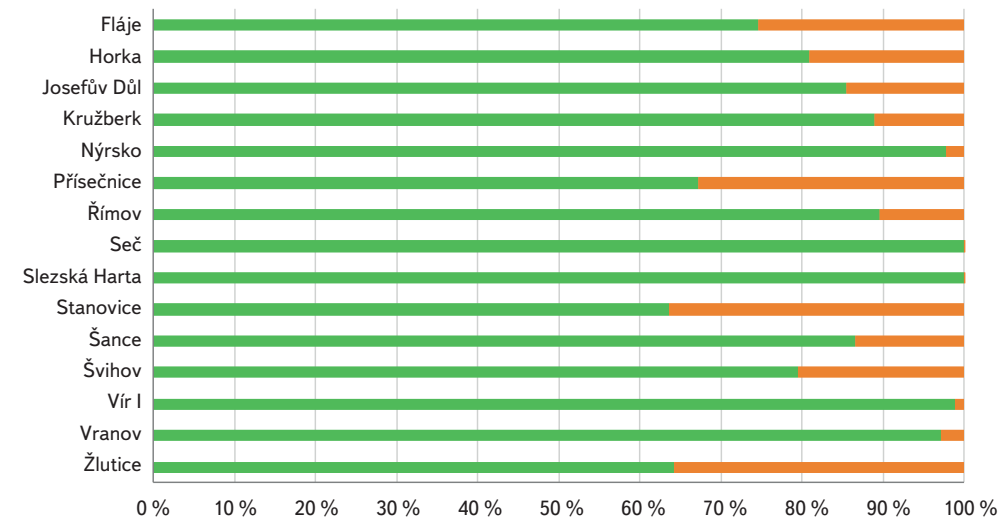

Odbĕr a MQ zajištěný prítokem Odběr a MQ zajištěnyy akumulaci

Obr. 8. Využití akumulace vody ve vodních nádržích pro zajištění současných odběrů vody a minimálních průtoků (scénár HadGEM2)

\section{DISKUZE}

Výsledky posouzení možných dopadů klimatické změny na dostupnost vodních zdrojů jsou prirozeně zatíženy jistou mírou nejistoty. Nejistota predikce dopadů klimatické změny na průtoky je reflektována volbou více možných scénár̆ů pro hydrologické modelování, počátečními a okrajovými podmínkami klimatických modelů a jejich strukturou. Dalšími nejistotami jsou výběr korekce systematických chyb klimatických modelů a struktura hydrologického modelu (modelování různými hydrologickými modely). Ze studií porovnávajících podíl jednotlivých zdrojů nejistot na celkovou nejistotu $\vee$ hydrologickém modelování vyplývá, že nejistota pramenící z modelování budoucího klimatu (struktura modelu) značně převyšuje nejistotu svázanou s volbou emisního scénáre nebo nejistotu vyplývající z hydrologického modelování. Celková nejistota promítnutá do výsledku hydrologického modelování je značná.

Určitou nejistotu rovněž představují budoucí změny $v$ požadavcích na odběry vody nebo zajištění minimálních průtoků (např. i s ohledem na prípadné dopady klimatické změny na jakost vody). Řada posuzovaných vodních nádrží a odběrů vody je součástí vodárenských soustav. Případné deficity tak mohou být u některých vodních nádrží pokryty jinými disponibilními vodními zdroji v soustavě, ale i naopak v období sucha může vzniknout požadavek na zvýšení odběrů z vodních nádrží k pokrytí deficitů ostatních, zranitelnějších zdrojů soustavy (odběrů prímo z vodních toků nebo odběrů podzemní vody). Řešení bylo zpracováno variantně pro současné skutečné odběry a odběry povolené. Do výsledků se tak ve značné míre promítá i nízký podíl využití povolených hodnot (viz tab. 1). Vyhodnocená nízká zabezpečenost povolených hodnot odběrů u některých vodních nádrží může být v budoucnu limitující pro případné napojení dalších spotřebišt na tyto zdroje.

\section{ZÁVĚR}

Cílem výše popsaného řešení bylo identifikovat potenciální problémy zpưsobené dopady klimatické změny k časové úrovni roku 2050 při zásobování pitnou vodou zajištovaném vodními nádržemi. Při řešení byly aplikovány metody hydrologické a vodohospodářské bilance, včetně simulačního modelování zásobní funkce vodohospodářských soustav. Pomocí použitých modelů byl kvantifikován možný dopad klimatické změny na hydrologické charakteristiky (zejména průtoky) a následně vyhodnocena zabezpečenost vodárenských odběrů zajištovaných vodními nádržemi. Hodnocené lokality (vodní nádrže a místa odběrů vody) Ize podle výsledné zabezpečenosti orientačně rozdělit do

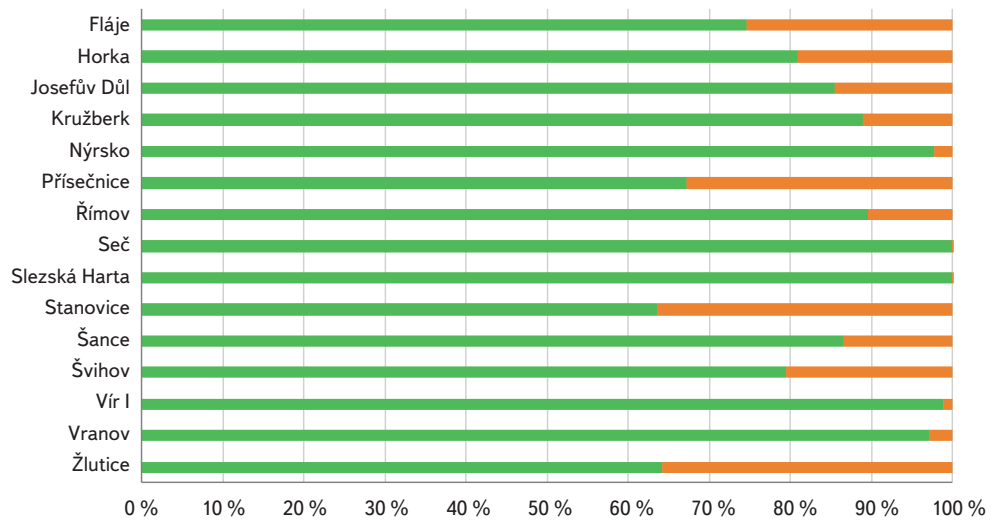

Demand and MQ secured by a tributary Demand and MQ secured by accumulation

Fig. 8. Use of water accumulation in the storage space of water reservoirs for the security of current water demand and minimum discharges in the HadGEM2 scenario

The following water reservoirs have been evaluated as having a high risk with regard to the security of water demand in climate change conditions: Stanovice, Žlutice, Pilská, Obecnice, Opatovice, Bojkovice, Mariánské Lázně Podhora, Klíčava and Nová Říše. Medium risk has been evaluated in water reservoirs Vranov - Znojmo, Vrchlice, Slušovice, Koryčany and Ludkovice. Problemfree security of current and permitted water demand has been evaluated in water reservoirs Římov, Nýrsko, Horka, Lučina, Slezská Harta - Kružberk, Seč - Křižanovice, Jirkov, Myslivny, Josefưv Důl, Souš, Mostiště, Hubenov and Landštejn.

Fig. 8 illustrates the impact of using water accumulation in the storage space of water reservoirs on the security of current requirements for drinking water demand and minimum discharges in water courses downstream from water reservoirs. A share of the volume of these requirements has been expressed that may be ensured only by an inflow into a water reservoir as well as a share that may be secured only with the help of water accumulation in the storage space. The whole length of the time series of the simulation has been evaluated for water reservoirs with a storage space volume over 10 mil. $\mathrm{m}^{3}$. With regard to simulation of the storage function in the monthly time step (when mean monthly discharges are considered), the impact of discharge variability in the course of individual months has been disregarded.

\section{DISCUSSION}

The results of assessing potential climate change impacts on the availability of water resources are naturally burdened with some degree of uncertainty. Uncertainty of prediction of climate change impacts on discharges has been reflected by choosing multiple possible scenarios for hydrological modelling, initial and marginal climate model conditions and their structure. Other uncertainties include selecting the correction of systematic errors of climate models and structure of the hydrological model (modelling by means of various hydrological models). Studies comparing the share of individual sources of uncertainty on the overall uncertainty in hydrological modelling shows that uncertainty that stems from future climate modelling (model structure) significantly exceeds uncertainty related to selecting an emission scenario or uncertainty that follows from hydrological modelling. The overall uncertainty reflected in the result of hydrological modelling is considerable.

Future changes of water demand requirements or the security of minimum discharges represent some uncertainty too (for instance also with regard to potential climate change impacts on water quality). Numerous assessed water 
několika skupin. Z celkem 45 hodnocených vodních nádrží jich bylo 15 vyhodnoceno jako bezproblémové jak pro všechny scénáře klimatické změny, tak pro skutečné i povolené odběry ( $z$ větších vodních nádrží mj. Římov, Kružberk Slezská Harta, Horka). U dalších 13 vodních nádrží byla vyhodnocena bezproblémová zabezpečenost u obou scénáru klimatické změny pouze pro současné hodnoty odběrů (mj. Švihov, Nýrsko, Vír I, Přísečnice, Fláje a Šance). Naopak střední riziko nedostatečného zabezpečení odběrů vody bylo identifikováno u 7 vodních nádrži (mj. Vranov - Znojmo a Stanovice) a vysoké riziko u 10 vodních nádrží (mj. Žlutice). Predikce zabezpečenosti odběrư v podmínkách klimatické změny je přirozeně zatížena nejistotami řešení jak s ohledem na nezbytné zjednodušení komplexní problematiky při jejím modelování, tak s ohledem na další vývoj na straně požadavků na odběry vody (včetně jejich fungování $\checkmark$ rámci větších vodárenských soustav) i zajištění minimálních průtoků.

\section{Poděkování}

Článek vznikl na základě výzkumu prováděného v rámci projektu VI20192022159 "Vodohospodářské a vodárenské soustavy a preventivní opatření ke snižení rizik při zásobování pitnou vodou" programu BV III/1-VS, který financuje Ministerstvo vnitra ČR.

\section{Poznámky}

1. Reprezentativní směry vývoje koncentrací (RCP). Jsou označeny podle približného celkového radiačního působení v roce 2100 v porovnání s rokem 1750 .

2. V deskriptivní (popisné) statistice je boxplot neboli krabicový graf či krabicový diagram jeden ze způsobů grafické vizualizace numerických dat pomocí jejich kvartilů. Střední „krabicová“ část diagramu je shora ohraničena 3. kvartilem, zespodu 1. kvartilem a mezi nimi se nachází linie vymezující medián. Body „outliers” zobrazují odlehlé hodnoty (mimo rozpětí 5-95 \%). reservoirs and water demands are part of water supply systems. Potential deficits in certain water reservoirs may therefore be met by other available water resources in the system; however, on the contrary a requirement may arise to increase water demand from water reservoirs to meet a deficit of other more vulnerable resources in the system (abstraction directly from watercourses or groundwater abstraction). Alternatives have been elaborated for current actual demands and permitted demands. The low share of using permitted values (see Tab. 1) is reflected in the results to a considerable extent. The evaluated low security of permitted water abstraction values in some water reservoirs may be limiting in the future for potential connection of other customers to these resources.

\section{CONCLUSION}

The aim of the above analysis has been to identify potential problems caused by climate change impacts in the timeframe of the year 2050 with respect to drinking water supply provided for by water reservoirs. Hydrological and water management balance procedures have been applied, including modelling of the storage function of water management systems. A potential climate change impact on hydrological characteristics (especially discharges) has been quantified by the applied models, and the security of drinking water demand provided for by water reservoirs has been subsequently evaluated. According to the security that has resulted from the above, the evaluated sites (water reservoirs and water abstraction sites) may be roughly divided into several groups. Out of a total of 45 evaluated water reservoirs, 15 have been evaluated as problem-free for all climate change scenarios as well as for actual demand and permitted water abstraction (among others Římov, Kružberk - Slezská Harta, Horka from the larger water reservoirs); in 13 other water reservoirs a problem-free security has been evaluated in both climate change scenarios only for current demand levels (among others Švihov, Nýrsko, Vír I, Přísečnice, Fláje and Šance). On the contrary, a medium risk of insufficient security of water demand has been identified in 7 water reservoirs (among others Vranov - Znojmo and Stanovice) and a high risk has been established in 10 water reservoirs (among others Žlutice). Prediction of the security of water demand in climate change conditions is naturally burdened with uncertainties both with regard to the necessary simplification of a complex issue in the modelling as well as with regard to further development concerning requirements for water demand (including its functioning within larger water supply systems) and the security of minimum discharges.

\section{Notes}

1. Representative Concentration Pathways (RCPs). They are designated according to the approximate total radiation effect in 2100 in comparison with 1750.

2. In descriptive statistics, a boxplot or a box-and-whisker plot or a box-andwhisker diagram is one of the modes of graphical visualisation of numerical data by their quartiles. The middle "box" part of the diagram is delimited by the $3^{\text {rd }}$ quartile from the top, by the $1^{\text {st }}$ quartile from the bottom, with a line between them that delimits the median value. The "outliers" are points that represent outlying values (outside the 5-95\% range). 


\section{Literatura}

[1] Vyhláška č. 431/2001 Sb., o obsahu vodní bilance, způsobu jejího sestavení a o údajích pro vodní bilanci [2] BERAN, A. a kol., Metodika pro navrhování adaptačních opatření k eliminaci dopadů nedostatku vody. VúV TGM, v. v. i., 2019, certifikovaná metodika MZe. ISBN 978-80-87402-70-2.

[3] Vyhláška č. 137/1999 Ministerstva životního prostředí, kterou se stanoví seznam vodárenských nádrží a zásady pro stanovení a změny ochranných pásem vodních zdrojủ

[4] HANEL, M., VIZINA. A., MARTÍNKOVÁ, M., \& FENDEKOVÁ, M., Changes of drought characteristics in small Czech and Slovakian catchments projected by th CMIP5 GCM ensemble, 2014

[5] ŠTĚPÁNEK, P. a kol., Očekávané klimatické podmínky v České republice. 2019. Vydáno v rámci projektu: "SustES - Adaptační strategie pro udržitelnost ekosystémových služeb a potravinové bezpečnost v neprízznivých prírodních podmínkách" (CZ.02.1.01/0.0/0.0/16_019/0000797)“. ISBN. 978-8-87902-28-8.

[6] VIZINA, A., HANEL, M. a kol. Středni scénář klimatické změny pro vodní hospodářstvív České republice, zprávy pro státnípodniky povodí. VúV TGM, v. v. i. 2019

[7] TALLAKSEN, L. M., \& VAN LANEN, H. A. (Eds.), Hydrological drought:processes and estimation methods for streamflow and groundwater. 2004

[8] VIZINA, A., HORÁČEK, S., \& HANEL, M., Recent developments of the BILAN model. Vodohospodářské technicko-ekonomické informace, 2015, roč. 57, č. 4-5, s. 7-10

[9] MELIŠOVÁ, E., VIZINA, A., STAPONITES, L. R., \& HANEL, M., The Role of Hydrological Signatures in Calibration of Conceptual Hydrological Model. Water, 2020, 12(12), 3401

[10] GUDMUNDSSON, L., BREMNES, J. B., HAUGEN, J. E., \& ENGEN-SKAUGEN, T., Downscaling RCM precipitation to the station scale using statistical transformations-a comparison of methods. Hydrology and Earth System Sciences. 2012, 16(9), 3383-3390

[11] VYSKOČ, P., ZEMAN, V., Metodický postup zpracování vodohospodárské bilance současného a výhledového stavu množstvi povrchových vod. Praha: VúV TGM, v. v. i. 2008

[12] PICEK, J., VYSKOČ, P. a ZEMAN, V. Simulační model množství povrchových vod: zásobni funkce vodohospodárské soustavy. Praha: VúV TGM, v. v. i. 2008

[13] ČSN 752405 Vodohospodářská řešení vodních nádrží

\section{Autoři}

Ing. Adam Vizina, Ph.D.

凶adam.vizina@vuv.cz

ORCID: 0000-0002-4683-9624

\section{Ing. Petr Vyskoč}

凶petr.vyskoc@vuv.cz

ORCID: 0000-0002-5006-5414

\section{Ing. Martina Peláková}

凶martina.pelakova@vuv.cz

ORCID: 0000-0003-0485-1542

\section{Ing. Jiří Picek}

凶jiri.picek@vuv.cz

ORCID: 0000-0002-6978-6801

\section{Ing. Adam Beran}

凶adam.beran@vuv.cz

ORCID: 0000-0002-8800-5599

\section{Ing. Roman Kožín}

凶roman.kozin@vuv.cz

ORCID: 0000-0002-5773-6567

Výzkumný ústav vodohospodářský T. G. Masaryka

Příspěvek prošel lektorským řízením

\section{Acknowledgements}

The study has been elaborated on the basis of a research conducted within No. VI20192022159 "Water Management and Water Supply Systems and Preventive Measures to Reduce Risks for Drinking Water Supply" under programme No. BV III/1-VS, which is funded by the Ministry of the Interior of the Czech Republic. 